\title{
Arquitectura regionalista en Galicia: de la mirada al románico a la revalorización barroco.
}

\author{
José RAMÓN IGLESIAs VeIGA ${ }^{1}$ \\ Regionalist Architecture in Galicia: From a look to Romanic to \\ the Baroque revaluation.
}

\begin{abstract}
RESUMEN
El artículo analiza la búsqueda de contenidos en la historia a la hora de definir una arquitectura regionalista en Galicia en las primeras décadas del siglo $X X$. Esa mirada se contextualiza en una metodología similar a la que emplea el

galleguismo en la afirmación de la identidad y cultura propia. En la arquitectura el proceso llevó a valorar la arquitectura popular y las milenarias tradiciones de la cantería granítica, a admirar el románico y a descubrir la singularidad del barroco compostelano. También se examina la importancia de la divulgación de los valores del patrimonio

para que la sociedad reconociese complacida aquellos elementos procedentes de la tradición que sus arquitectos incorporaban a sus creaciones.
\end{abstract}

\section{PALABRAS CLAVE}

Regionalismo, arquitectura, barroco, románico, granito, Galicia, pintoresco, eclecticismo.

\begin{abstract}
This article discusses the search for heritage contents in order to define regionalist architecture in Galicia during the first decades of the 20th century. The context of this perspective is established under a methodology similar to the one used in the defense of the Galician culture and self-identity. In architecture, this process led to appreciate the folk's architecture and a-thousand-year tradition of stone working in granite stone, to admire Romanic and to discover the singularity of the Compostela Baroque style. Moreover, it is also examined the importance of spreading the heritage values so that the society could recognize the elements coming from the traditional style in the architects' creations.
\end{abstract}

\section{KEYWORDS}

Regionalism, architecture, Baroque, Romanic, granite, Galicia, picturesque, eclecticism.

${ }^{1}$ Doctor en Historia por la UNED. Instituto de Estudios Vigueses. Correo: monchoveiga@ gmail.com 
La arquitectura gallega de las primeras décadas del siglo XX asumió con fuerza la corriente regionalista. Al igual que en otros puntos de España, se concretaron propuestas singulares y diferenciadas, si bien no alcanzaron la difusión de las generadas en los focos sevillano, vasco o cántabro. Su definición fue también un poco más tardía, ya que necesitó de ciertos impulsos relacionados con el ambiente cultural que potenciaba el galleguismo. El regionalismo encontró un campo abonado en los gustos conservadores de una sociedad tradicional, con escaso desarrollo tecnológico e industrial. La arquitectura siguió asumiendo un papel representativo de la posición alcanzada con los negocios o la incipiente industria. Los suntuosos chalés regionalistas fueron escaparate de una joven burguesía, que en Vigo se había consolidado con las actividades marítimas y el auge del sector conservero. Esta ciudad fue la única que en Galicia concretó un proceso industrial al transformarse el salazón de pescado en conserva en lata. En ese momento las clases acomodadas gallegas también sostenían con sus compras la plástica regionalista liderada por Sotomayor, Llorens y Asorey. Ciertos proyectos de marcado contenido galaico optaron por un lenguaje regionalista, como sucede con la Residencia de Estudiantes de la Universidad de Santiago. Además de acaparar la arquitectura doméstica, esta tendencia se incorporó a diversas tipologías, como casas consistoriales, estaciones de ferrocarril, escuelas, etc.

Además de la influencia del contexto de la arquitectura española, la presencia de la tendencia regionalista en Galicia necesitó de una demanda interna nacida en el ambiente de potenciación de la lengua y cultura propia. La intensificación de la actividad cultural desplegada por el galleguismo a partir de la creación de las Irmandades da Fala en 1916 generó un requerimiento de vinculación del arte con lo vernáculo al que no fue ajeno la arquitectura. En ese empeño, los miembros de la generación Nós estarían más cerca de una expresión diferenciada y regionalista de la arquitectura que de una aproximación a una distante vanguardia que, con su propuesta de universalización de la forma, pudiera interferir en la potenciación de lo propio. Para reclamar una arquitectura entroncada en lo vernáculo no fue necesario asumir posiciones ideológicas ligadas al galleguismo, ya que bastó con despertar un nuevo sentimiento por la tierra, lengua, paisaje, estilos históricos, tradiciones, etc. Personalidades ajenas a la militancia galleguista, como la escritora Pardo Bazán, reclamaron en público una expresión regionalista galaica. Esta tendencia conectó con fuerza con la sociedad del momento y gozó de una aceptación superior a la que tuvieron otros estilos en las primeras décadas del siglo XX.

\section{LA MIRADA ERUDITA AL PASADO.}

La búsqueda de contenidos en la historia que proporcionaran a la arquitectura una expresión propia se enmarca en el ambiente cultural de una época en la que el galleguismo buscaba en el pasado argumentos sobre los que sustentar los rasgos de la personalidad diferenciada de Galicia. El interés por el pasado, que arrancara 
en el Rexurdimento de la mano de los historiadores románticos, se acelera en las primeras décadas de siglo XX y fructifica en la publicación de numerosos estudios centrados en la historia, lingüística, arqueología, etnografía, folclore, etc. El patrimonio arquitectónico no quedó al margen, por lo que los monumentos comienzan a ser visitados y estudiados, descubriéndose la singularidad de la expresión de ciertos estilos. En ese proceso destaca una primera aportación de archiveros que al aproximarse al monumento con métodos basados en la consulta de documentos superan la mera evocación de eruditos románticos como Neira de Mosquera o Vesteiro Torres. Entre ellos se encuentra José Villaamil y Castro que, formado en la Escuela Superior de Diplomática de Madrid, dejó una abundante producción con estudios de las catedrales de Santiago Lugo y Mondoñedo. Manuel Martínez Murguía fue uno de los primeros en mostrar una actitud compresiva hacia la expresión del barroco en Galicia, cuando todavía prevalecían los prejuicios generados con la implantación del gusto neoclásico. En 1884 publica $^{2}$. El Arte en Santiago durante el siglo XVIII, monografía en la que se aproxima a la obra de Andrade, Casas y Novoa, Ferro Caaveiro, Simón Rodríguez, etc. Colabora con un capítulo dedicado a su tierra en la obra España, sus monumentos y artes. Su naturaleza e historia, editada en 1884 como reedición de Recuerdos y bellezas de España en la que no aparecía Galicia ${ }^{3}$. Antonio López Ferreiro fue otro archivero que se acercó al patrimonio con una metodología caracterizada por la consulta sistemática de documentos, como refleja la revista Galicia Histórica, que dirige y la ingente obra Historia de la Santa A. M. Iglesia de Santiago de Compostela, publicada en once tomos entre 1898 y 1911.

La Comisión de Monumentos Históricos y Artísticos de Ourense, bajo la dirección de Marcelo Macías, realizó una importante labor. Entre sus logros se encuentra la creación del Museo Arqueológico Provincial en 1895 y el impulso de estudios sobre el patrimonio, que después ven la luz en el Boletín de la Comisión al lado de otros de carácter histórico o arqueológico. También fue notable la actividad de la Sociedad Arqueológica de Pontevedra, que funda en 1894 Casto Sampedro Folgar. Además de abarcar campos como la música y el folclore, fue pionera en el empleo del dibujo y la fotografía en la catalogación del patrimonio arqueológico y arquitectónico. En la formación de su importante archivo gráfico contó con los fotógrafos Zagala y Sáenz Mon y los artistas Campo Sobrino, Alcoverro, Carlos Sobrino, etc. La Real Academia Gallega no dejó de prestar atención a la arquitectura histórica y acogió en su boletín estudios sobre monasterios, castillos e iglesias del medio rural. En la labor individual destacan Couselo Bouzas, Pérez Constanti y Ángel del Castillo López. Este último, archivero del ayuntamiento de A Coruña, además de un intenso trabajo de catalogación, realizó una entusiasta tarea divul-

${ }^{2}$ MURGÍA, M., El arte en Santiago durante el siglo XVIII y noticia de los artistas que florecieron en dicha ciudad y centuria, Madrid, Est. Tip. de Fernando Fe, 1884.

${ }^{3}$ MURGÍA, M., "Galicia» en España, sus monumentos y artes. Su naturaleza e historia, Barcelona, Establecimiento Tipográfico-Editorial de Daniel Cortezo y Cía, 1888. (Facsímil, Ed. Xerais, 2000). 
gativa. La constitución en 1923 del Seminario de Estudios Gallegos supuso un nuevo avance en el conocimiento de la arquitectura histórica, tanto culta como popular. En otros puntos de la geografía española que buscaban afianzar sus señas de identidad se localizan instituciones similares, como el Institut d'Estudis Catalans, creado en 1907 bajo la iniciativa de Enric Prat de la Riba. Para abordar la realidad gallega en su conjunto el Seminario se estructuró en secciones y adoptó métodos científicos de carácter interdisciplinar que implicaban la colaboración entre las secciones. Al lado de expertos como Ángel del Castillo, otros investigadores formados en el propio Seminario, como Filgueira Valverde, Carro García, Bouza Brey, Taboada Roca y González García-Paz dieron continuidad a la catalogación y al estudio de elementos de patrimonio. Algunos de sus trabajos vieron la luz en los seis tomos de la revista Arquivos, editados entre 1926 y 1934.

\section{EL INTERÉS DE LOS ARQUITECTOS POR EL ESTUDIO Y CONSERVACIÓN DEL PATRIMONIO.}

Al estudio de la arquitectura histórica se sumaron también destacados arquitectos como Antonio Palacios Ramilo, Miguel Durán-Loriga Salgado, Robustiano Fernández Cochón, Constantino Candeira, Eloy Maquieira, etc. Algunos de ellos se integraron en el Seminario de Estudios Gallegos y colaboraron en la realización de trabajos colectivos. Su acercamiento al patrimonio fue desigual, ya que en unos primó lo emotivo y nostálgico, mientras en otros adquirió un carácter más científico con la consulta de documentos y contacto directo con el monumento. Uno de los primeros interesados fue Antonio Palacios (1874-1945), arquitecto de gran prestigio en Madrid y, por esa razón, mitificado por la prensa gallega. Sin asumir militancia o compromiso ideológico, se dejó seducir por los aspectos culturales del galleguismo y se implicó en el estudio y divulgación de la riqueza monumental de su tierra. Inducido por este ambiente buscó definir una arquitectura regionalista galaica, que sólo consideró válida para ciertas tipologías y para espacios alejados del centro cosmopolita de la ciudad, donde se inclinó por otro tipo de soluciones ${ }^{4}$. El interés por establecer un lazo con la historia deriva también de su formación académica al lado profesores implicados en la restauración como Velázquez Bosco, Vicente Lámperez y Manuel Aníbal Álvarez. Las alusiones a la relación con este último aparecen en los artículos e intervenciones del arquitecto. En 1926 Palacios se reconoce como su discípulo en el acto de recepción en la Academia de San Fernando: «Quiero hacer presente aquí que, en lo que al ardiente deseo de nacionalización de este Arte se refiere, el gran impulso definitivo corresponde exclusivamente a mi maestro y maestro de toda la actual generación de Arquitectos D. Manuel Aníbal Álvarez, del cual el más humilde discípulo se presenta ante vosotros».

\footnotetext{
${ }^{4}$ Sobre la aparente contradicción entre lo cosmopolita y lo regionalista, véase: IGLESIAS VEIGA, J. R., «Antonio Palacios: arquitecto metropolitano y arquitecto regionalista», Antonio Palacios, constructor de Madrid, Madrid, Ed. La Librería, 2001, págs. 202-244.
} 
Al igual que hizo Rucabado en Santander o Domènech en Cataluña, Palacios recorrió Galicia y el norte de Portugal con la intención de conocer su riqueza monumental, si bien no existió un objetivo definido de realizar un estudio erudito o sistemático. Prestó especial atención a la arquitectura del ambiente rural, sobre todo a los grandes monasterios y extendió su curiosidad a Portugal, dentro de la proximidad que en el ambiente galleguista se sintió hacia el país vecino. En una entrevista ${ }^{5}$ concedida en Lisboa en 1927, el arquitecto afirma que Galicia, más que otra región española, debía ser considerada por los portugueses como una prolongación de su espíritu nacional. Incide también en la importancia de una mayor colaboración entre los dos países. Como fruto de esa reciprocidad, propone editar una gran publicación sobre los estilos que considera más peculiares: «la arquitectura más característicamente peninsular es precisamente el 'manuelino' portugués, arquitectura hermana de lo que empieza a llamarse en España 'estilo Isabel' y al cual los críticos franceses reconocen más originalidad, como una cosa aparte de los estilos europeos". Es posible que el conocimiento de ciertos monumentos portugueses actuara de referente de alguna de sus obras gallegas. En el caso de la compleja planta del templo de la Veracruz de O Carballiño pudo ser la iglesia de Santo Cristo de Tomar, en la que se combina una planta octogonal románica con una rectangular manuelina. La alusión a las iglesias de planta central del Temple está presente en otros proyectos, como el del templo de la Paz del monte de la Guía de Vigo (1932, no ejecutado).

Antonio Palacios publicó una larga serie de artículos de temática variada en los periódicos Faro de Vigo, El Pueblo Gallego y Galicia (Diario de Vigo) y en las revistas Vida Gallega y Céltiga. Entre los más numerosos, unos se relacionan con el patrimonio y otros con la promoción de sus propuestas, en especial del plan urbanístico de Vigo. Los primeros tienen un carácter divulgativo y se distancian de la línea erudita que asumieron otros compañeros como Torres Balbás. Reflejan la idealización de un nostálgico pasado, la atracción que sintió por los monumentos de su tierra, la impresión que le produjeron ciertas soluciones y el conocimiento de los estudios de la erudición gallega: «López Ferreiro cuya figura se agiganta más cuanto más se le estudia. Murgía, menos documentado, pero más tenaz. Villamil, Balsa de la Vega, Marcelo Macías y tantos otros cuya labor se nos presenta como verdaderamente admirable ${ }^{6}$ En 1928 , en la presentación del proyecto de reforma de los accesos a la catedral de Ourense vuelve a destacar la labor de López Ferreiro, así como la de Marcelo Macías y de otros investigadores. También resalta el estudio de la catedral de Santiago de Kenneth John Conan. La imagen medieval de esta catedral, definida por este arquitecto americano, sirvió, en palabras del propio Palacios ${ }^{7}$, como referente en 1932 en el diseño del templo de Panxón en Nigrán (fig. 1), junto a la de las catedrales de Ourense, Tui y Coimbra. (Sée-Velha).

\footnotetext{
5 «Viajero ilustre. Arquitectura em Portugal e em Espanha» en El Pueblo Gallego, 15-VI-1927, pág. 1.

${ }^{6}$ PALACIOS RAMILO, A., «El Monasterio de Osera» en Boletín de la Comisión Provincial de Monumentos Históricos y Artísticos de Orense, tomo VII, no 159, XI y XII de 1924, págs. 225-228.

7 «La extensión urbana de Panjón y su nueva iglesia parroquial» en Faro de Vigo, 26-XI-1932, pág. 3.
} 


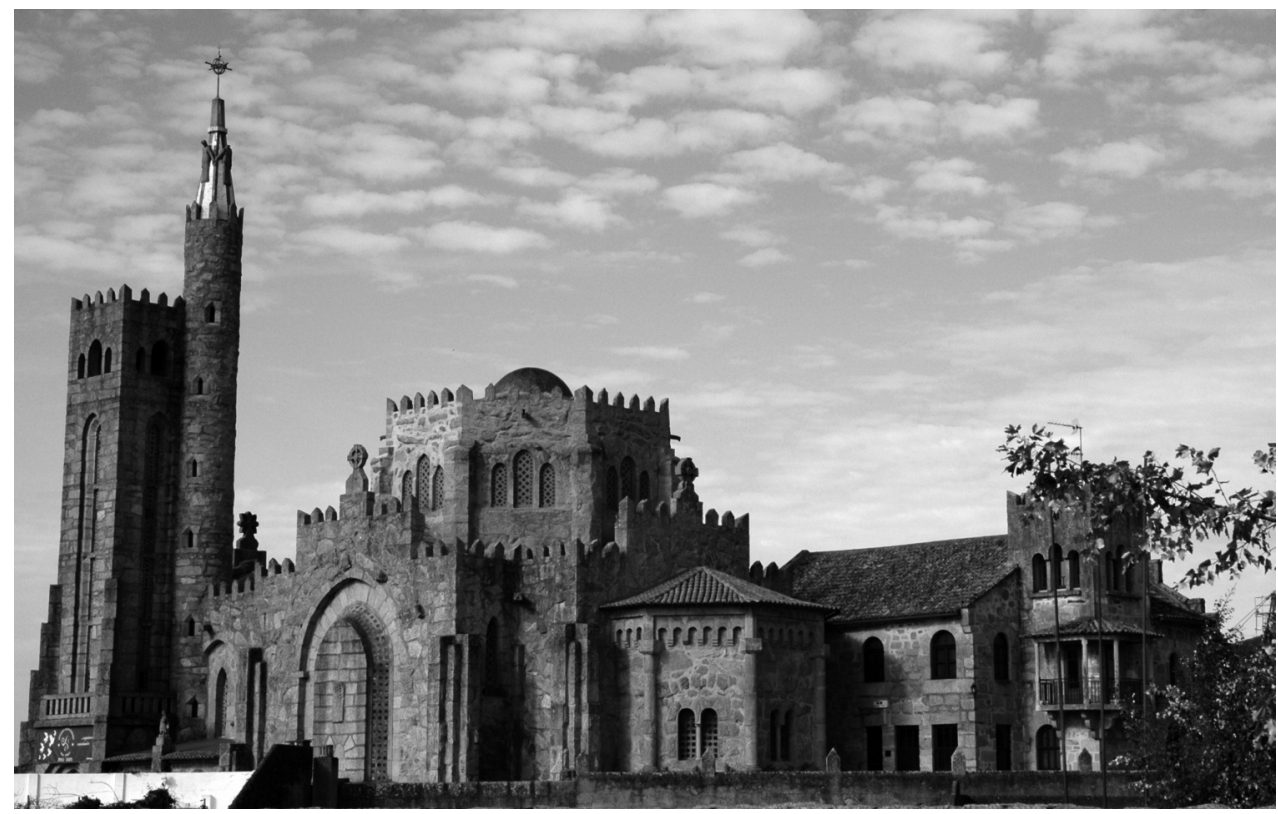

Fig. 1. Templo Votivo de Panxón en Nigrán (Pontevedra). Antonio Palacios Ramilo. 1932.

En otras ocasiones menciona la consulta de trabajos de Martínez Santa-Olalla, a quien cita en un artículo de 1931 sobre la iglesia burgalesa de Moradillo de Sedano, en el que describe ciertos elementos que reflejan influencia gallega ${ }^{8}$. También aparecen reseñas de contactos con personalidades ligadas al Centro de Estudios Históricos, como Gómez Moreno y Sánchez Cantón. Con este último colaboró en el estudio de distribución del Museo de «Arte Gallego» en el pazo de Castrelos de Vigo.

En 1925 Antonio Palacios publica en primera página del periódico Faro de $V_{\text {Vigo }}{ }^{9}$ un extenso texto sobre el Hospital Real de la compostelana plaza del Obradoiro, que ilustra con un plano de planta que localizó en la Biblioteca Archivo del Palacio Real de Madrid. En este escrito lanza la propuesta de convertir el inmueble renacentista en un lujoso hotel, como años más tarde se hizo. En 1927 escribe sobre el Pórtico de la Gloria ${ }^{10}$ y analiza su tratamiento estereotómico, al considerar que la obra del maestro Mateo era tan extraordinaria desde el

${ }^{8}$ PALACIOS RAMILO, A., «Expansión de la arquitectura románica gallega: La iglesia de Moradillo de Sedano» en Faro de Vigo, 12-II-1931, pág. 8; La Construcción Moderna, no 5, 15-III-1931; MARTíNEZ SANTA-OLALLA, J., «La iglesia románica de Moradillo de Sedano» en Archivo Español de Arte, n 6, 1930, págs. 267-275.

${ }^{9}$ PALACIOS RAMILO, A., «La Hospedería Real de Santiago de Compostela» en Faro de Vigo, 14-II1925, pág. 1.

10 PALACIOS RAMILO, A., «Del Pórtico de la Gloria. Notas para su estudio estereotómico» en Faro de Vigo, 21-VIII-1927, pág. 1-2; Vida Gallega, no 354, 10-XI-1927. 
punto de vista constructivo, como por sus valores estéticos y escultóricos. En este texto y en otros se comprueba su alto aprecio de la milenaria tradición de la cantería, lo que le llevó a otorgarle protagonismo en su propuesta de intención regionalista: «Allí estaba patente, gritando ante el más ciego, la evidencia de que el Pórtico de la Gloria de Santiago, es, como os dije al principio, tan notable por su estructuración estereotómica, como por su primordial importancia iconográfica. Su genuino galleguismo, queda identificado también, una vez más, por la sabiduría que resalta en el manejo del corte de piedras -habilidad que perdura en nuestros maestros canteros hasta nuestros propios días- y las sagaces precauciones adoptadas en los más menudos detalles constructivos». La fascinación por ciertos elementos de los monumentos que visita, se manifiesta en el artículo dedicado al monasterio de Armenteira, del que destaca la presencia en la iglesia de una cúpula de inspiración musulmana. A este descubrimiento le dedica la mayor parte del texto, con comentarios sobre sus características, posible origen y relaciones con otras obras ${ }^{11}$. La impresión de su visita al monasterio de Oseira, que recoge en otro de sus escritos ${ }^{12}$, se percibe en el templo de la Veracruz de $\mathrm{O}$ Carballiño, en una concepción de la girola que parece recrear lo observado en la iglesia de este monasterio. Con un carácter más divulgativo escribe para alguna revista gallega de la emigración. En 1927 publica en la revista bonaerense Céltiga un artículo sobre el Pórtico del Paraíso de la catedral de Ourense y al año siguiente otro sobre las ceremonias que debía realizar el peregrino que llegaba a la catedral compostelana ${ }^{13}$.

La preocupación por la divulgación del patrimonio aparece también en las intervenciones públicas de Palacios. En noviembre de 1931, en un ciclo de conferencias organizado por la sociedad «La Oliva» de Vigo, diserta sobre las iglesias románicas de Bembrive, Corujo y Castrelos ${ }^{14}$. El arquitecto se consideraba un experto en arquitectura medieval y así lo hizo constar como mérito en el concurso de anteproyectos de la parroquial de San Francisco en Santander. Su atención también se detuvo en la construcción popular y en las soluciones nacidas de su adaptación al clima y a los materiales. El 9 de octubre de 1930, presentado por Castelao, pronuncia una conferencia en el Círculo Mercantil de Vigo bajo el epígrafe «Aportación al estudio de la casa popular gallega». En ella analizó los invariantes generados por la imbricación del hombre con el medio a lo largo de los siglos que evidenciaban la existencia de una arquitectura popular gallega a la que recomienda mirar para mantener la tradición de un arte singular,

${ }^{11}$ PALACIOS RAMILO, A., «Armenteira» en Galicia. Diario de Vigo, 1-I-1926, págs. 4-5; «El Monasterio de Armenteira» en Vida Gallega, no 295, 10-II-1926.

12 PALACIOS RAMILO, A., «El Monasterio de Osera» en Boletín de la Comisión Provincial de Monumentos Históricos y Artísticos de Orense, no 159, XI-XII de 1924, págs. 225-228.

${ }^{13}$ PALACIOS RAMILO, A., «EI Pórtico del Paraíso de la Catedral de Orense» en Céltiga, Buenos Aires, $\mathrm{n}^{\circ}$ 63, 10-VIII-1927; «Unha apreta, un croque, un bico» en Céltiga, nำ89, 10-IX-1928. También Faro de Vigo, 25-VII-1929, pág. 12.

14 «La conferencia de La Oliva. El Gran Palacios disertando» en Faro de Vigo, 22-XI-1931, pág. 5; «En La Oliva. Conferencia del señor Palacios» en El Pueblo Gallego, 20-XI-1931, pág. 6. 

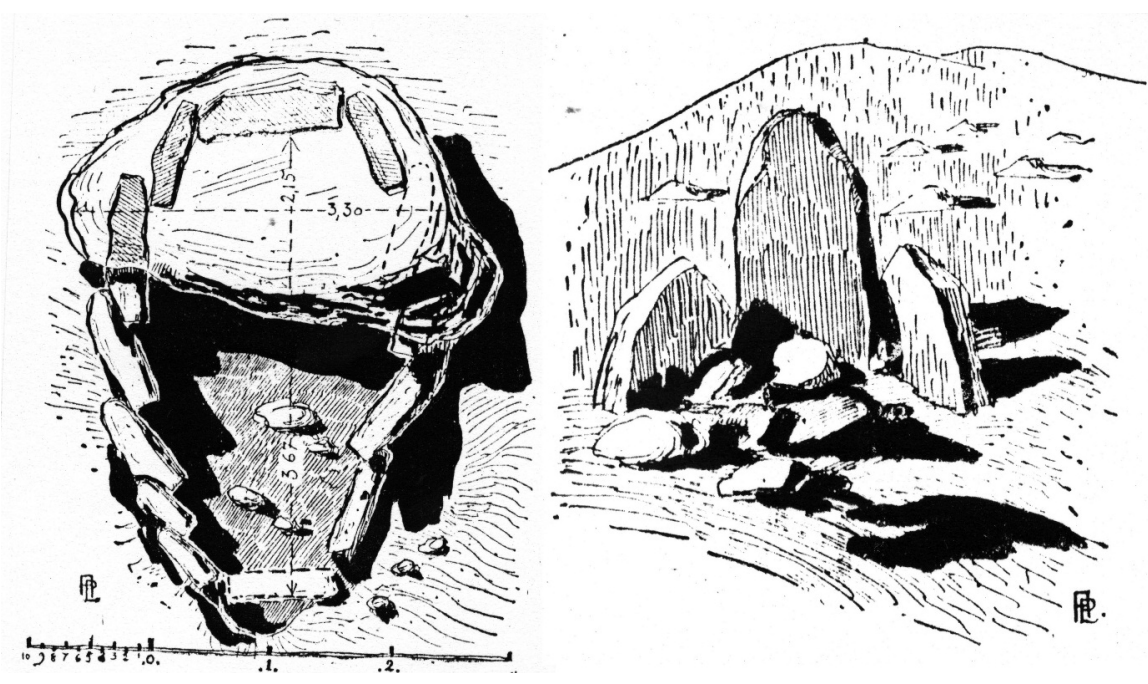

Fig. 2. Dibujos de Antonio Palacios. Restos de la necrópolis dolménica de San Colmado en Cela, Mos (El Pueblo Gallego, 1931).

aunque incorporando todos los elementos modernos de higiene y confort ${ }^{15}$. Su intervención se enmarca en un ciclo de conferencias sobre la personalidad diferenciada de Galicia que organizó el Grupo Autonomista Galego, presidido por su amigo Paz Andrade. Aspectos de esa especificidad en la lengua, geografía, paisaje, literatura etc. fueron tratados por personalidades del galleguismo como Otero Pedrayo, Castelao, Cotarelo Valledor, Filgueira Valverde, Risco, García Martí, etc. En la obra de aliento regionalista de Palacios se percibe ese acercamiento a la construcción popular, sobre todo en relación con los tratamientos del granito. La sencillez de lo rural se evidencia en las propuestas de vivienda obrera que concreta para el proyecto, no ejecutado, de la Barriada de la Espiñeira de Santiago de Compostela (1930). La atención que recibe la arquitectura histórica es en parte deudora del protagonismo que alcanza la arqueología en relación con la búsqueda de referentes de la identidad de Galicia. Esa circunstancia no pasó desapercibida para Antonio Palacios, que publica dos artículos relacionados con la arqueología. En el primero, que redacta al descubrir la necrópolis dolménica de San Colmado (Cela, Mos), muestra su fascinación por la primera arquitectura gallega que representan los dólmenes. Como fue habitual, ilustra el texto con dibujos realizados al tomar contacto con estos restos (fig. 2). El segundo artículo desvela como se interesó por técnicas modernas en este campo, como la fotografía aérea para localizar yacimientos arqueológicos ${ }^{16}$.

15 «Aportación al estudio de la casa popular gallega» en Faro de Vigo, 10-X-1930, pág. 1; «Una bella disertación de Palacios» en El Pueblo Gallego, 10-X-1930, pág. 3; «Como debe ser la casa gallega» en Vida Gallega, no 464, 20-X-1930.

${ }^{16}$ PALACIOS RAMILO, A., «Por la Galicia Céltica. Una ciudad de hace tres mil años a media hora de Vigo» en El Pueblo Gallego, 15-XI-1931, pág. 8; «La Arqueología de Galicia. Bajo la mirada de las águilas» en Faro de Vigo, 30-XI-1932, pág. 12. 
En su preocupación por el patrimonio, Palacios se interesó por los grandes monumentos y valoró menos los conjuntos de arquitectura popular, como el barrio marinero del Berbés en Vigo, que proponía derribar en su Proyecto de Ensanche y Reforma Interior de Vigo (1932). A principios de 1925 publica un extenso artículo sobre la conservación del patrimonio gallego, en el que denuncia el mal estado de muchos de sus elementos, en especial de los monasterios y de otras edificaciones del medio rural ${ }^{17}$. Criticaba también la escasa asignación que el Estado destinaba en Galicia a la restauración de monumentos y a las actividades artísticas. Para Palacios la arquitectura tenía un peso específico dentro del conjunto del arte gallego: «Puede afirmarse rotundamente que la más pura esencia del arte gallego de todos los tiempos está contenido en su Arquitectura». Al aludir a los monasterios comentaba la posibilidad de que la generosidad de los emigrados facilitase su recuperación, con una fórmula en la que los centros gallegos de cada república americana ejercerían el patronazgo sobre un monasterio que de este modo se convertiría en residencia para estancia de sus miembros en Galicia. En el artículo el arquitecto confirma como la mirada emotiva y nostálgica a un mitificado pasado afectó a su obra de impronta regionalista: «Queda prometido, desde ahora, que otro día hablaré de nuestra arquitectura gallega contemporánea. Pero precisamente tengo que declarar que al ser abordada tal cuestión, forzosamente habré de comenzar estableciendo que, para la buena cimentación de los posibles éxitos actuales, hemos de mirar amorosamente a ese nuestro pasado artístico". La prensa reseña acciones puntuales del arquitecto para proteger algún elemento patrimonial. Su preocupación le llevó en el año 1917 a denunciar los agresivos trabajos de limpieza de la fachada del templo de Santa María de Pontevedra y a realizar gestiones en Madrid que facilitaron la suspensión de las obras por la Comisión de Monumentos Históricos de Pontevedra ${ }^{18}$. En 1924 el escritor Valle Inclán reconoce públicamente ${ }^{19}$ que la intervención de Palacios salvó del derribo el renacentista pazo-torre de Bermúdez de A Pobra do Caramiñal (hoy museo Valle Inclán). En 1931 remite una carta a Casto Sampedro en la que se lamenta del abandono del monasterio de Carboeiro y de los desperfectos de sus fábricas por la maleza y las filtraciones de agua. Indica que realizaría gestiones en Madrid para evitar daños irreparables y comenta que en una de sus excursiones tomó fotografías y recogió datos para levantar secciones y plantas.

En 1928 en un artículo ${ }^{20}$ que ocupa toda la primera página de Faro de Vigo, Palacios propone la creación de una gran revista ilustrada que diera a conocer la cultura gallega y a la vez actuara de vínculo entre los emigrados. Incluiría secciones de arte moderno y antiguo, literatura, arqueología, historia, folclore, ciencias,

17 PALACIOS RAMILO, A., «La conservación de nuestro tesoro artístico regional» en Vida Gallega, no 268, 25-I-1925; El Pueblo Gallego, 1-I-1925, pág. 2.

18 «Pontevedra. El templo de Santa María» en Faro de Vigo, 16-IX-1917; «El templo de Santa María...» en Diario de Pontevedra, 17-IX-1917, pág. 1.

19 «Nuestras visitas (...) Palabras de Valle Inclán» en El Pueblo Gallego, 26-III-1924, pág. 12.

20 PALACIOS RAMILO, A., "Galicia» en Faro de Vigo, 6-XI-1928, pág. 1. 
agricultura, industria, etc. Si bien su propuesta fue recibida con complacencia, afloran las primeras críticas por parte de una generación más joven y progresista que se aleja del regionalismo y se acerca a las corrientes internacionales. Eugenio Montes, comparte la necesidad de una revista gallega, pero censura la forma de entender el arte y la literatura del arquitecto y de los miembros de su generación, a los que achaca falta de modernidad y atraso en relación con las corrientes de la época ${ }^{21}$. En la polémica tercia Antón Villar Ponte con una posición conciliatoria que busca no perder la labor de consolidación de la cultura propia. Propone la convivencia de las dos posturas, al considerar que no sería excluyente otra publicación dedicada al «arte nuevo» en la que los artistas jóvenes exhibieran sus experiencias innovadoras 22 . El comentario de Montes responde a las aspiraciones de una nueva generación que pretende una actualización del pensamiento artístico y dotar de contenidos más universales a la creación gallega. Esa aspiración comienza a concretarse en el inicio de la década de 1930 en la obra de Maside, Laxeiro, Souto, Torres, Seoane, Colmeiro, etc. En el artículo Palacios evidencia la simpatía que sintió hacia el ambiente de potenciación de la cultura propia: «Galicia está en plena razón para realizarse. Surgen todos los días con pletórica savia nuevos artistas, algunos, tal pintor, tal dibujante, los mejores de España. Aquí y allá aparecen escultores de primer orden, arquitectos, grabadores, tallistas, orfebres. El conocimiento de nuestra vieja, magnífica arquitectura nos trae cada día una nueva sorprendente revelación».

En uno de estos escritos ${ }^{23}$ Palacios destaca la pasión por el estudio de los monumentos gallegos de su compañero Miguel Durán Loriga-Salgado (1886-1950). Este arquitecto coruñés, titulado en 1915, ejerció su profesión en Madrid, ciudad en la que desde 1923 trabajó como arquitecto del Ministerio de Hacienda. Se acercó también a la dimensión cultural de galleguismo y mantuvo contactos con Ramón Otero Pedrayo y Vicente Risco. En 1925 publica un artículo sobre el Monasterio de Ribas de Sil24, que ya había divulgado en una disertación en el Centro Gallego de Madrid. La atención al patrimonio, en especial al mundo de los pazos, se refleja en su proyecto del Pabellón de Galicia en la Exposición Iberoamericana de Sevilla de 1929. La arquitectura doméstica compostelana y la obra de Domingo Luis Monteagudo también fueron objeto de estudio ${ }^{25}$. El interés por la arquitectura de los pazos le llevó entre los años 1945 y 1950 a realizar una intensa investigación que no llegó concretar en una publicación. Gran parte del material recogido, con abundancia de notas y fotografías, se encuentra en el Museo de Pontevedra y consti-

\footnotetext{
${ }^{21}$ MONTES, E., «La revista literaria gallega» en EL Pueblo Gallego, 22-V-1929, pág. 1.

22 VILLAR PONTE, A., «Tocando Terra» en El Pueblo Gallego, 26-V-1929, pág. 1.

${ }^{23}$ PALACIOS RAMILO, A., «La conservación de nuestro... Op Cit.

${ }^{24}$ DURÁN, M., «El monasterio de San Esteban de Ribas de Sil» en El Pueblo Gallego, 4-I-1925, pág. 8.

${ }^{25}$ DURÁN SALGADO, M., «Unos planos inéditos del arquitecto Lois Monteagudo» en Boletín de la Real Academia Gallega, no 241, Vol. XXI, 1932; «Domingo Lois Monteagudo» en Revista Nacional de Arquitectura, 1948, págs., 462-464; El arquitecto gallego Lois Monteagudo» en Arte Español, 1941, pág. 1417; «La casa compostelana» en Galicia. Revista mensual ilustrada, Madrid, no 19, julio de 1935, págs. 105-107; Archivo de Arte y Arqueología, Madrid, 1926.
} 


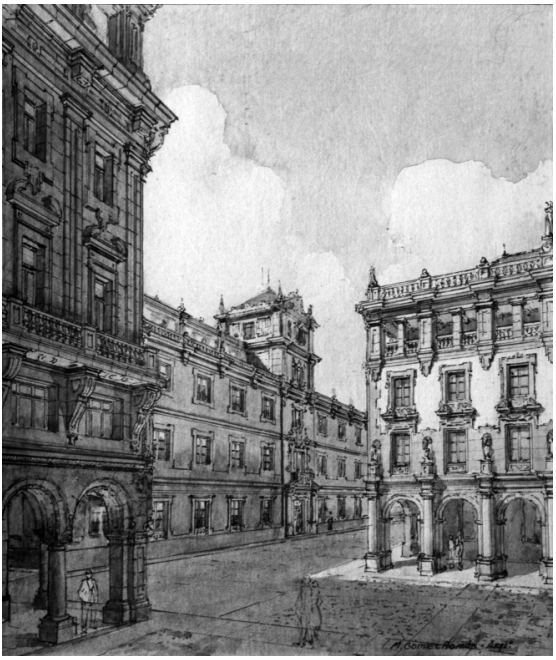

Fig. 3. «Plaza. Fantasía». Manuel Gómez Román. (Fundación Penzol. Vigo).

tuye hoy un importante legado para el estudio de esta tradicional tipología gallega. En la posguerra publica estudios sobre el pazo de Mariñán en A Coruña y sobre el monasterio de Samos en la provincia de Lugo ${ }^{26}$.

Los arquitectos Manuel Gómez Román, Constantino Candeira, Robustiano Fernández Cochón y Eloy Maquieira colaboraron en las actividades del Seminario de Estudios Gallegos. Gómez Román asumió un claro compromiso político y desempeñó el cargo de secretario general del Partido Galleguista antes de la Guerra Civil, con intensa participación en la promoción del Estatuto de Autonomía. También fue miembro del Seminario y tuvo a su cargo la sección de Ciencias Aplicadas que asume en marzo de 1933, tras ser creada a petición de los ingenieros vigueses Antonio Fernández y Juan Ogando ${ }^{27}$. Si bien Gómez Román, a diferencia de Palacios, no se prodigó en la publicación de artículos sobre la arquitectura histórica, ni tampoco sobre sus proyectos, en su obra, bosquejos (fig. 3) e intervenciones públicas se percibe un marcado interés por el conocimiento de los estilos históricos, en especial del barroco. Su amigo, el escritor Francisco Fernández del Rie$\mathrm{go}^{28}$, comentaba como admiró de este estilo la capacidad que tuvo en Galicia para adecuarse al paisaje y a las tradiciones constructivas en granito. En ese contexto se enmarca su mirada al barroco de placas compostelano a la hora de buscar una arquitectura específica del lugar que, sin renunciar a una cierta modernidad, estableciera un diálogo con la tradición y con los condicionantes del me-

${ }^{26}$ DURÁN SALGADO, M., La Real abadía de S. Julián de Samos. Estudio histórico arqueológico, Madrid, Imprenta Blass, 1947; «El pazo de Mariñán. Bergondo» en Anuario Brigantino, no 1, 1949.

27 «Todos los días. Una sección del Seminario de Estudios Gallegos en Vigo» en El Pueblo Gallego, 24-III-1933, pág. 5. «Seminario de Estudios Gallegos» en El Compostelano, 10-III-1933, pág. 2.

${ }^{28}$ FERNANDEZ DEL RIEGO, F., «A xeito de presentación» en GARRIDO RODRÍGUEZ, X. e IGLESIAS VEIGA, X. Mª R., Manuel Gómez Román. Mestre... Op. Cit., pág. 8. 
dio geográfico. Pasados los años y en una ocasión tan solmene como la de su ingreso en la Real Academia Gallega, rememoraba su predilección por ese estilo: «Mais o espirito da galeguidade remaneceu forte e vibradoiro no Barroco. Estilo que en Galicia, máis que estilo dunha época, hai que o considerar como fase de superación, de exuberante evolución das etapas precedentes. $E$ iso ata tal punto que chegou a constituír a nosa xenuína maneira de expresión (...) Ese estilo resplandece aínda nas vilas e cidades galegas con calidades de perfecta manifestación, ou con cambios de certa inxenuidade, pero sempre nunha liña de acorde continuista. Co barroco completouse e formación da cidade compostelana, Museo de Arquitectura de crecente estimanza para cantos nesta orde cifran os seus afáns»29.

Constantino Candeira Pérez(1892-1962), fue otro de los arquitectos que se implicó en el conocimiento de la riqueza monumental de su tierra. Ya en los años de formación en Madrid estableciera amistad con Torres Balbás y con el historiador Sánchez Cantón. En 1924 fue nombrado arquitecto municipal de Santiago de Compostela, cargo que desempeña hasta que a principios de 1930 asume la plaza de arquitecto de la Diputación Provincial de Valladolid. Como arquitecto municipal tuvo intención ${ }^{30}$ de crear una comisión auxiliar para asesorar al ayuntamiento en actuaciones en el casco histórico de Santiago que «abarquen desde los faroles y rótulos, hasta el estilo y aspecto de las construcciones». En un artículo publicado en 1926, bajo el epígrafe «El futuro pasado», volvía a mostrar su preocupación por una correcta conservación del patrimonio compostelano: «Porque la ciudad es algo vivo; y, porque vive y ha de seguir viviendo, se necesita uncir a la tradición las necesidades del presente; sin mutilaciones inútiles; enmendando los yerros de las demasiado seguras 'correcciones' y tratando de llevar en nuestra mano la simpatía en vez del odio. (....) El año Santo de 1926 debe ser para Santiago el año de su canonización; el año en que sus restos adquieran el valor de una reliquia»31. Candeira ingresó en el Seminario de Estudios Gallegos el 23 de octubre de 1926 con un discurso titulado, «Síntesis de la evolución del barroco en Santiago», que refleja la recuperación de este estilo al ser escogido como tema en una ocasión tan solmene. Díaz Pardo señalaba que este discurso, hoy perdido, fue considerado como excepcional por Otero Pedrayo en relación con el conocimiento del barroco compostelano ${ }^{32}$. El arquitecto asume la dirección de la sección de Catalogación Iconográfica del Seminario que desempeña hasta abril de 1928, fecha en la que renuncia debido a sus ocupaciones profesionales. Su labor de catalogación fue continuada por Jesús Carro García, intelectual al que el propio arquitecto propuso para substituirle. En 1926 la prensa destacaba la labor de esta sección y del ingente trabajo realizado en el «Catálogo iconográfico de la riqueza

${ }^{29}$ GÓMEZ ROMÁN, M., «Encol dunha arquitectura galega» en Grial, nº 56, abril-mayo-junio, 1977, págs. 217-219; Obradoiro, nº 17, septiembre de 1990, págs. 18-21. 37.

${ }^{30}$ SONEIRA BELOSO, B., O arquitecto Constantino Candeira, Sada, Ed. do Castro, 2006, págs. 24-

${ }^{31}$ CANDEIRA PEREZ, C., . «El futuro pasado» en Faro de Vigo, 1-I-1926, pág. 32.

${ }^{32}$ SONEIRA BELOSO, B., O arquitecto... Op. Cit.. Texto de la contraportada de Isaac Díaz Pardo. 
artística gallega». Se reseñaba el empleo de un moderno sistema de fichas que incorporaba fotografías y datos de cada monumento ${ }^{33}$. El catálogo se había ampliado en 1930 a más de un millar de fichas con fotografías, plantas, alzados, dibujos, descripciones y notas bibliográficas ${ }^{34}$. En 1934, con la intervención de Carro, Filgueira Valverde y González García-Paz, las secciones de Arqueología e Historia del Arte del Seminario realizaron un trabajo de catalogación de más de cincuenta iglesias románicas. Candeira también realizó tareas de divulgación y en marzo de 1927, en un acto organizado por la Facultad de Filosofía y Letras de la Universidad de Santiago, disertó sobre la arquitectura de la época de los Reyes Católicos ${ }^{35}$. Tras establecerse en 1930 en Valladolid, recogió gran cantidad de referencias documentales y de fotografías del patrimonio castellano que hoy se conservan en la Fundación Joaquín Díaz. Por la arquitectura histórica gallega también se interesó el pontevedrés Eloy Maquieira (1901-1944), arquitecto municipal de Lugo desde 1927. En 1926 ingresa en el Seminario de Estudios Gallegos y con este motivo presenta una monografía sobre la iglesia románica de Ansemil (Silleda) que realizó con Candeira ${ }^{36}$. Los dos técnicos llegaron a estudiar la iglesia de Santa María la Mayor y Real del Sar en Santiago. Robustiano Fernández Cochón colaboró con el citado Seminario y se integró en actividades colectivas de catalogación y de estudio de diversas comarcas ${ }^{37}$. Rafael González Villar se acercó al conocimiento de la arquitectura popular, si bien esta actividad tuvo poca repercusión en su obra.

\section{DE LA MIRADA A LOS ESTILOS MEDIEVALES A LA REVALORIZACIÓN DEL BARROCO.}

En el contexto de búsqueda en el pasado de referentes de la cultura y de la identidad propia, ciertas manifestaciones de la arquitectura popular y la expresión singular de algunos estilos obtuvieron la categoría de representativas de lo gallego. Este proceso estuvo condicionado por la diversa fortuna historiográfica de los estilos, lo que mediatizó a los arquitectos en su elección de contenidos a la hora de definir una arquitectura de aliento regionalista y reconocible como propia. Antonio Palacios, como primer técnico que busca en Galicia esa definición, fija su atención en el medievo y opta por la seguridad de una práctica que había mostrado su validez en Francia, Alemania e Inglaterra para significar con el neogótico un sentimiento de nacionalidad. En Cataluña la apreciación de su pasado medieval, en especial de la etapa de esplendor que se corresponde con el gótico, tuvo eco a finales del XIX en las propuestas arquitectónicas. Destacados arquitectos, como

33 «La catalogación iconográfica de los monumentos de Galicia...» en Faro de Vigo, 31-X-1926, pág. 1.

34 «El Seminario de Estudios Gallegos...» en Faro de Vigo, 25-VII-1930, pág. 24.

35 «Noticias» en El Compostelano, 4-III-1927, pág. 3.

36 «Un arquitecto pontevedrés» en El Progreso (Pontevedra), 24-XI-1926, pág.2; «Seminario de Estudios Gallegos, ingreso de un pontevedrés» en El Pueblo Gallego, 23-XI-1926, pág. 10.

37 «Seminario de Estudios Gallegos...» en El Pueblo Gallego, 19-V-1934, pág. 8. 
Domènech i Montaner y Puig i Cadafalch, se implicaron además en el estudio de ese pasado. El primero destacó por su contribución al conocimiento del románico con una ardua labor de investigación por toda Cataluña. En su acercamiento al medievo y a las tradiciones constructivas, Palacios se distancia de los que entendieron el regionalismo como aprovisionamiento de citas en el pasado. Su vínculo con lo vernáculo fue una excusa para hacer una arquitectura original y de sello personal que recrea el pasado, pero nunca lo reproduce literalmente ${ }^{38}$. Incluso el empleo de ciertos recursos formales neomedievales fue subjetivo y se escapa a una arqueológica adscripción a monumentos históricos concretos. Sus coetáneos no consideraron la obra de Palacios como una copia de estilos del pasado, sino más bien como una creación exclusiva e inconfundible, tal como indicaba Jaime Solá ${ }^{39}$ : «Palacios tiene su estilo gallego de estos días (...) Es románica la iglesia de Panjón? No, sin duda. ¿Es gótica? No es gótica ¿Es románica de transición o es gótica incipiente? Tampoco. Nos acercaríamos a una relativa realidad si dijésemos que es la visión, en sueños, de quien pudiese fundir en un estilo lo que hay de idea de lo románico y de idea de lo gótico en el ambiente arquitectónico gallego. Pero mejor será decir que la iglesia de Panjón es de estilo... de Palacios»

El carácter heterodoxo y libre de la creación de aliento regionalista de Antonio Palacios hizo que fuese poco comprendida y que apenas tuviera seguidores. Más que ejercer el liderato en un tipo de propuesta, influyó en sus compañeros en la apertura de una vía regionalista, al mostrarles que sus primeros proyectos en este parcela del templo de la Encarnación de Celanova (1918, no ejecutado) y sobre todo el de la casa consistorial de O Porriño (1919) eran aceptados con complacencia ${ }^{40}$ por la sociedad de su época y por la intelectualidad galleguista (fig. 4). Su alto prestigio y la repercusión en la prensa de sus opiniones, contribuyeron a que otros arquitectos se sumasen en Galicia a esta tendencia ya en la década de 1920. En un momento de progresivo rescate del barroco, estos profesionales se dejan atraer por la variante de placas compostelana. Aunque en lo formal Palacios vuelve su mirada al medievo, en alguno de sus proyectos y sobre todo en sus concepciones urbanísticas se percibe el contacto con las escenografías barrocas. Como ha estudiado Villar Movellán ${ }^{41}$, en el regionalismo sevillano también se produce una doble apreciación del pasado, con una primera etapa ligada al mundo hispano-musulmán y una segunda que valora el barroco de la ciudad de Sevilla.

La incipiente recuperación del barroco, que el contexto europeo iniciaran Jacob Burckhardt y Heinrich Wölffin, comienza a manifestarse entre los arquitectos es-

38 Vid. IGLESIAS VEIGA, J. R., Antonio Palacios. Arquitecto. De O Porriño a Galicia, Pontevedra, Diputación, 1993; "Contenidos regionalistas en la arquitectura de Antonio Palacios en Galicia» en Espacio, Tiempo y Forma, Serie VII, Historia del Arte, Tomo, 7, Madrid, UNED, 1994, págs. 383-418.

${ }^{39}$ SOLÁ, J., «El templo votivo a la Virgen del Mar» en Vida Gallega, № 697, 10-X-1934.

${ }^{40}$ CABANILLAS, R., «Antonio Palacios. O arquitecto poeta» en Faro de Vigo, 31-VIII-1918, pág. 1. Da la primera noticia de este proyecto al que califica como el resurgir del arte gallego.

${ }^{41}$ VILLAR MOVELLÁN, A., Arquitectura del regionalismo en Sevilla, Sevilla, Diputación, 1979, pág. 43. 


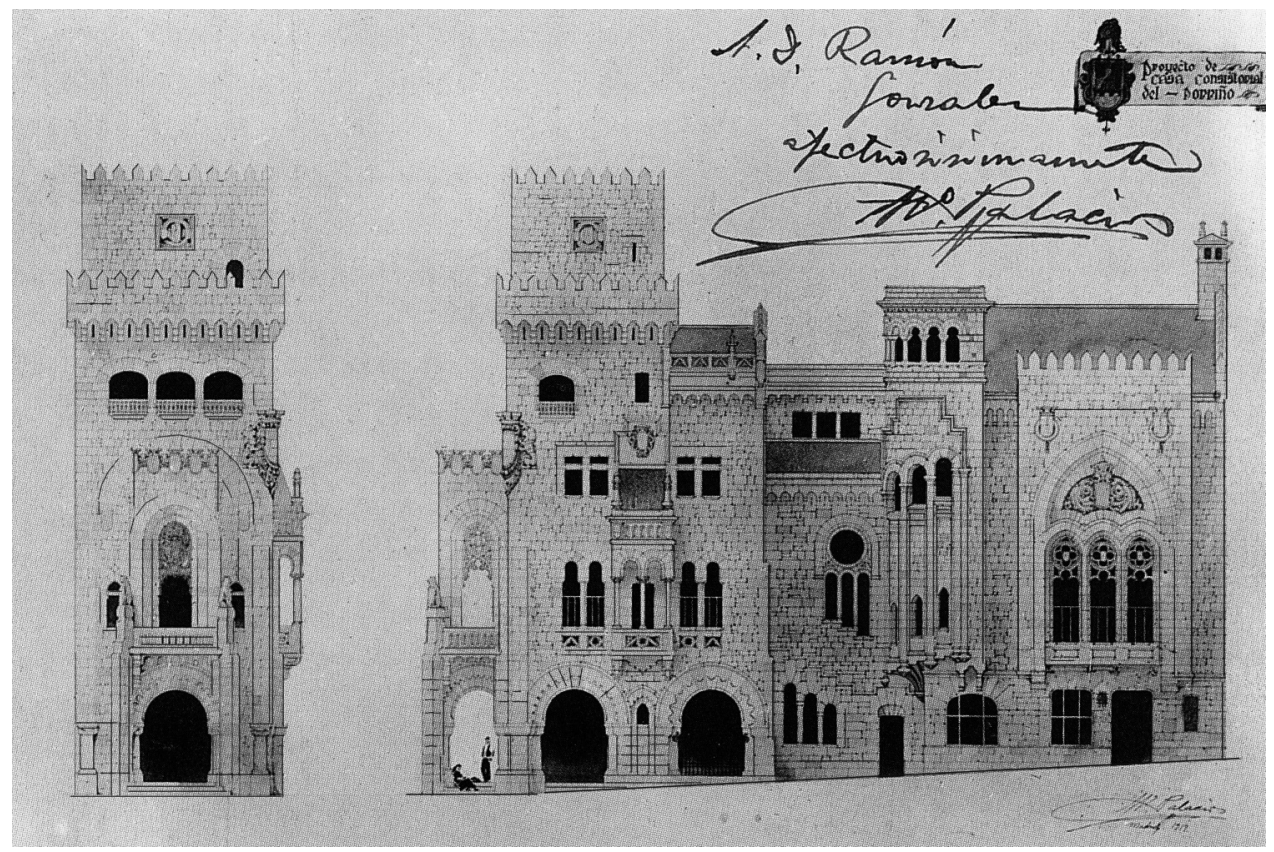

Fig. 4. Alzados de la casa consistorial de O Porriño, con dedicatoria al indiano que financió su construcción. Antonio Palacios Ramilo. 1919 (Porriño, 1895-1995. Recuerdos de un siglo).

pañoles a principios del siglo XX. En 1899 Arturo Mélida Alinari alude a este estilo en su discurso de ingreso en la Real Academia de San Fernando. Poco después, en 1917, en un discurso similar titulado Del barroquismo en Arquitectura, Manuel Zabala Gallardo aborda su evolución con las controversias y equívocos que había generado. Vicente Lampérez Romea, uno de los teóricos del tradicionalismo arquitectónico y profesor de muchos de los que asumen el regionalismo, muestra atención a los pazos gallegos en su obra Arquitectura civil española de los siglos I al XVIII (1922), con mención a los de Oca, Rivadulla, Picoña, Pegullal, Santhomé, Mariñán, etc. En la práctica arquitectónica, además de la mirada al barroco de ciertos focos regionalistas, existieron ejemplos de neobarroco que gozaron de difusión como la Casa del Cura (1912) del templo de San José de la Gran Vía madrileña de Juan Moya y Joaquín Fernández Menéndez. Aunque tardía, tuvo mayor repercusión la fachada del edificio de la Telefónica de Madrid (1926-1929) de Ignacio Cárdenas y Lewis S. Weeks. En la apreciación del barroco gallego por parte de los arquitectos regionalistas influyó la valoración de historiadores foráneos que incluyen a Galicia en sus estudios. Entre ellos destaca Otto Schubert que publica en 1908 Historia del barroco en España, editada en castellano ${ }^{42}$ en 1924 . El interés que

${ }^{42}$ SCHUBERT, O., Historia del barroco en España (1908), Madrid, Saturnino Calleja, 1924. 
despertaba el estudio de este estilo se refleja también en el número monográfico que la revista Arquitectura le dedica en 1920, con inclusión de un apartado sobre Galicia que firma Leopoldo Torres Balbás.

Dentro de la erudición local, además de las primeras contribuciones de Murguía, destaca la labor de Pablo Pérez Constanti que, como archivero, incorpora una importante documentación en su obra Diccionario de artistas que florecieron en Galicia durante los siglos XVI y XVII (1930) y Couselo Bouzas que en 1933 publica Galicia Artística en el siglo XVIII y primer tercio del XIX (1933). En ese momento ya se había consolidado la apreciación de la singularidad del barroco por parte de los arquitectos que asumían los postulados regionalistas, como se comprueba en la obra y en los idealizados dibujos de Gómez Román. El resto de profesionales que en la década de 1920 se incorporan a esta corriente se adhieren también a la vía neobarroca. La investigación tuvo continuidad en otros eruditos como Manuel Chamoso Lamas que en algunos textos publicados antes de la Guerra Civil deja ver como el referente de Santiago de Compostela como la ciudad que reúne las esencias del arte gallego no había dejado de crecer. Esa consideración se acrecentaba ahora con el descubrimiento de la peculiaridad del barroco de placas: «Santiago no es una ciudad medieval más que por su tradición, mientras que por su estructura es una ciudad del siglo XVIII, una ciudad barroca, con espíritu y personalidad totalmente barrocos»43. En la posguerra la recuperación del barroco recibe nuevas aportaciones, como la del propio Lamas que en 1955 publica La Arquitectura Barroca en Galicia ${ }^{44}$. Destaca la ingente investigación que Antonio Bonet Correa realiza por toda la geografía gallega y concreta en 1957 en su tesis doctoral, publicada en 1965 bajo el título ${ }^{45}$ La arquitectura en Galicia durante el siglo XVII. Fuera del campo de la investigación, la evocación literaria del mundo de los pazos está presente en obras de Otero Pedrayo, Losada Diéguez, Emilia Pardo Bazán, Valle Inclán, Fernández Flórez, etc. El interés por la arquitectura popular fue menor que la generada por los estilos cultos. A su estudio se acercaron en Galicia eruditos como Xaquín Lorenzo, López Cuevillas, Bouza Brey, Fernández Ojea, etc. que en la etapa anterior a la Guerra Civil colaboran con el Seminario de Estudios Galegos en trabajos colectivos ${ }^{46}$. También Ángel del Castillo la abordó puntualmente con el estudio de las singulares pallozas de Os Ancares y O Cebreiro ${ }^{47}$. Las alusiones a la arquitectura popular gallega son escasas en las publicaciones españolas de las tres primeras décadas del siglo XX. Los hórreos y las pallozas aparecen en el libro del arquitecto racionalista Fernando García Mercadal sobre la casa popular en España ${ }^{48}$.

${ }^{43}$ CHAMOSO LAMAS, M., «Santiago de Compostela. Ciudad barroca» en Faro de Vigo, 1-I-1935, pág. 11; «La fachada del Obradoiro de la catedral de Santiago de Compostela» en Archivo Español de Arte y Arqueología, no 36, Madrid, 1936.

${ }^{44}$ CHAMOSO LAMAS, M., La arquitectura barroca en Galicia, Madrid, CSIC, 1955.

${ }^{45}$ BONET CORREA, A., La arquitectura en Galicia en el siglo XVII, Madrid, CSIC, 1966.

${ }^{46}$ Vila de Calvos de Randín (1930); Terra de Melide (1933); Parroquia de Velle (1936).

${ }^{47}$ CASTILLO LÓPEZ, A del, «Por las montañas de Galicia...» en Boletín de la Real Academia Gallega, núms. 78 y 82, 1913 y 1914; Vida Gallega, № 53, 15-IIl-1914 y Alfar, no 31, julio de 1923.

${ }^{48}$ GARCÍA MERCADAL, F., La casa popular en España, Espasa Calpe, 1930. (Gustavo Gili, 1981). 
La mirada que los arquitectos dirigen al pasado para recoger contenidos de lo propio se vio reforzada por el papel que el galleguismo otorgaba a la historia a la hora de asentar un sentimiento de identidad. Incluso algunas etapas de especial relevancia dentro del papel concedido al «espíritu del pueblo» o Volksgeist en la definición de la teoría nacionalista, se presentaron en correspondencia con su expresión arquitectónica. En ese sentido Otero Pedrayo exaltaba las primeras construcciones prehistóricas, el románico y el barroco: $E$ a Galicia chegóu a ista mestría en catro momentos do tempo. No céltigo, no románico, no barroco, no romántico. Certamente, con diferente forza e intensidade en cada ún, i en todos dunha maneira incompleta, porque todas as obras dos homes son demarcadas e endexamais completas no tempo histórico. Pra enxergar o valor e a significanza de cada momento podémolos simbolizar no dolmen da gándara, no poema ou no pórtico románico, na torre barroca, no verso dos Precursores ${ }^{49}$. La referencia a la portada románica y sobre todo a la torre barroca o pazo, que aparece también en la narrativa de Otero, se relaciona con la idealización de una Galicia rural y campesina que oponía al medio urbano al que consideraba desgalleguizado. La correspondencia de la arquitectura con esas etapas históricas la menciona de nuevo en Ensayo histórico sobre la cultura gallega (1933), obra clave en el análisis de la singularidad de la cultura propia.

Castelao también resalta la expresión arquitectónica de esos períodos históricos. En Sempre en Galiza ${ }^{50}$ establece una etapa diferenciada en la prehistoria, pero en su caso la sitúa en la cultura castrexa. Al aludir a la singularidad del románico y del barroco establece relaciones entre arte y nacionalidad: «As artes da construcción callaron en Galiza no estilo románico, que perdurou por riba do gótico, deica enlazarse co barroco. O gótico, por ser un arte lóxico, non pudo aclimatarse no noso país, pero do barroco fixemos un «estilo nacional». Porque tendes que saber que hai un "barroco galego", e que, neste estilo, creamos exemplares que son fitos da historia do arte». En ese contexto fijó su atención en los pazos y en abril de 1919, en el momento en que Palacios concretaba sus primeras propuestas de intención regionalista, pronuncia una conferencia en la sociedad «La Oliva» de Vigo, bajo el epígrafe "Arte y Galleguismo", en la que incluye a la arquitectura dentro de la búsqueda de una creación artística de carácter vernáculo. Tras citar al teórico inglés John Rukin e incidir en el amor al paisaje y en el respecto a la naturaleza, propone al pazo como base para crear un estilo de casa de campo gallega ${ }^{51}$. Esa recomendación vuelve a aparecer en la conferencia que en octubre de ese año, bajo el mismo epígrafe, pronuncia en A Coruña con motivo de la exposición de Imeldo Corral ${ }^{52}$. Significativo del papel que se le otorgaba a la ar-

49 OTERO PEDRAYO, R., Morte e resurrección, Ourense, 1932 (Recogido en BALIÑAS, C. Pensamento galego I, Vigo, Galaxia, 1977, págs. 99-132).

${ }^{50}$ CASTELAO, A. R., Sempre en Galiza (Buenos Aires, 1944), Vigo, Galaxia, 1986, págs. 46-47.

51 «Labor cultural. Conferencia de Castelao en la Oliva» en Faro de Vigo, 10-IV-1919, pág. 1; «Conferenza de Castelao. Arte e Galeguismo» en A Nosa Terra, no 85-86, 15-IV-1919.

${ }^{52}$ CASTELAO, A. R., Arte e galeguismo, A Coruña. Tip. El Noroeste, 1919. 


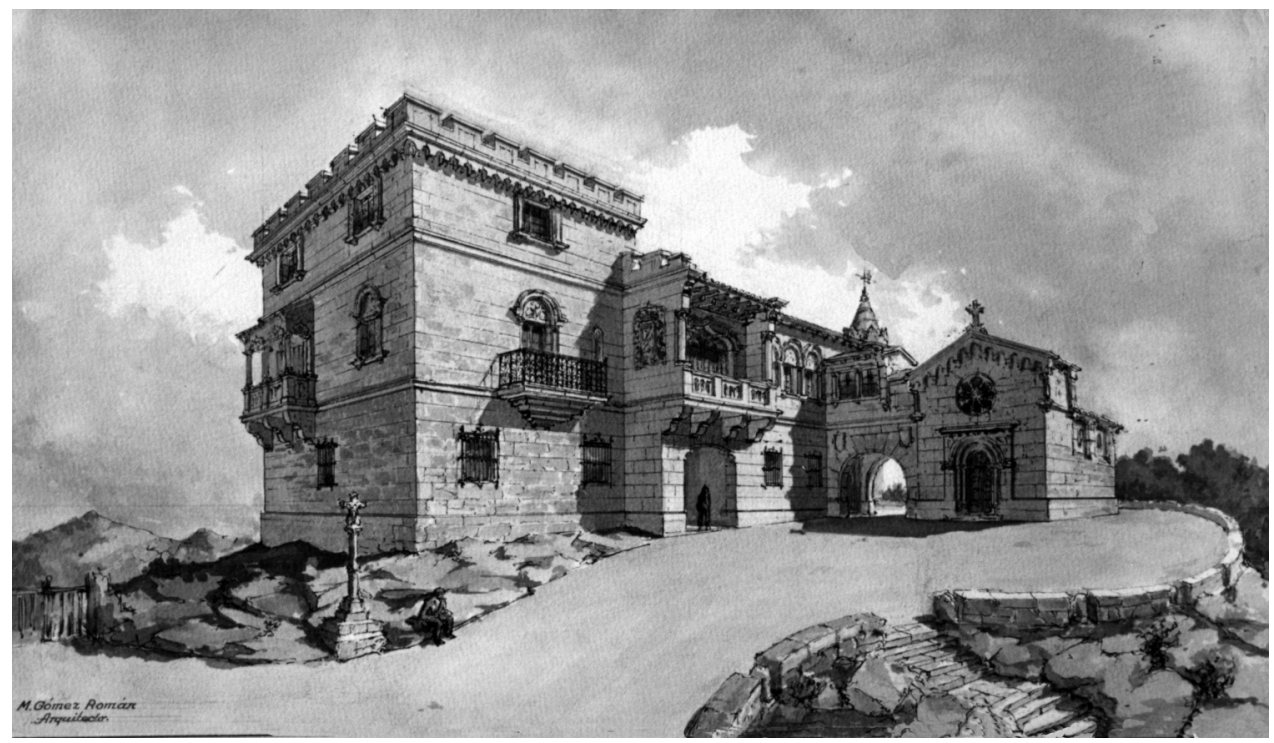

Fig. 5. Estudio de pazo inspirado en la torre de Friol (Lugo). Manuel Gómez Román. (Fundación Penzol. Vigo)

quitectura dentro de una estética de «raíces gallegas» fue el intento de que los planos de la casa consistorial de O Porriño, trazados por Palacios, acompañasen en marzo de 1920 a las estampas del Álbum Nós en su primera exposición en el Círculo de Artesanos de A Coruña ${ }^{53}$.

La apreciación del pazo (fig. 5), como expresión genuina del campo gallego, no es ajena a la importancia que el galleguismo concedía al medio rural como depositario de las esencias de lo propio y del recelo hacia la ciudad por considerarla contaminada de influencias cosmopolitas que podían actuar como disolvente de un sentimiento de nacionalidad ${ }^{54}$. El requerimiento de atención a las tipologías rurales está presente en otros focos regionalistas en los que también se producía un proceso de afirmación de sus señas de identidad. Ana Julia Gómez y Javier Ruiz ${ }^{55}$, en su estudio de la vivienda obrera en Bilbao, señalan la importancia del caserío en la definición de un regionalismo neovasco aplicado a un gran número de tipologías. En relación con el peso del ruralismo, pronto se repudiaron los modelos importados que se implantaban en el campo gallego. Castelao acuñó el término despectivo «arquitectura che» para nombrar aquellas viviendas que respondían a patrones ligados a los focos regionalistas españoles o a modelos internacionales

53 «Arte e galeguismo. Unha exposición do xenial Castelao» en A Nosa Terra, nํ 111, 25-I-1920.

${ }^{54}$ Vid. SÁNCHEZ GARCÍA, J. y IGLESIAS VEIGA, J. R., «Bases ideológicas para la recuperación del pazo gallego en los años 30» en Actas del Congreso Internacional: Arquitectura, ciudad e ideología antiurbana, ETSA, Universidad de Navarra, 2002, págs., 123-133.

${ }^{55}$ GÓMEZ GÓMEZ, A. J., y RUIZ SAN MIGUEL, J., Las casas baratas de Bilbao, Bilbao, Polidori, 2004, págs. $45-68$. 
de gusto pintoresco que se difundía a través de libros de repertorio o pattern books. La citada denominación y la de «villas estilo Buenos Aires» se dirige a modelos llevados al ambiente rural por indianos que regresaban enriquecidos a su tierra. La crítica también fue ejercida por arquitectos como Palacios: «En verdad son muy antipáticas las construcciones de imitación extranjera, de 'chalets pseudo-suízos' o 'pseudo-franceses' que ni por las razones del clima, ni, sobre todo, por las razones de estética, en que la arquitectura debe ser un complemento del paisaje, son de admitir y son una nota de desafinamiento en el conjunto armonioso entre el Arte y la Naturaleza» ${ }^{56}$. Sin embargo, el rechazo a lo foráneo, no impidió asumir una metodología que tenía en consideración las tradiciones constructivas locales, como sucedía en las variantes del cottage inglés de los estilos neotudor, Old English y Queen Anne. Esa consideración estaba también presente en la definición de las casas normanda, bretona, vasca, alpina, suiza, etc. que por influencia del gusto pintoresco surgieron en el continente europeo.

La defensa de una tipología imbricada en el medio geográfico está presente en periódicos no vinculados al galleguismo, en los que también se encuentra tolerancia hacia una arquitectura cosmopolita para la ciudad y rechazo a lo foráneo para el ambiente rural. En un editorial de Faro de Vigo ${ }^{57}$ de diciembre de 1925, después de elogiar la vivienda regionalista de Santander y Asturias, se indicaba: «Galicia no necesita que se falsifique su belleza natural adornándola con el artificio de «chalets» y jardines franceses; el encanto de la aldea está precisamente en su sencillez característica no profanada todavía por la ciencia de los arquitectos. Las construcciones de estilo extranjero pueden admitirse en las ciudades y en sus alrededores y aún creemos que para ello se podría buscar modelos dentro del propio país sin acudir a lo importado. En la aldea solo cabe la casa labriega -inuestra casa!- cómoda y amplia, con sus ventanas abiertas a la luz, dominando los extensos prados y labradíos (...) Hasta la solana y el patín pueden entrar en esas construcciones modernas sin perjuicio para su belleza».

Desde la propia erudición, además de señalar los trazos singulares de la expresión del barroco, se reclamó que esa peculiaridad sirviera de base para enunciar un regionalismo galaico. El historiador Ángel del Castillo, se mostraba favorable, al igual que Castelao, a la definición de una estilo de casa de campo basada en el pazo. En una conferencia que pronuncia en febrero de 1926 en A Coruña y poco después repite en Santiago y Monforte, al comentar la relación que establecieran los pazos con el clima y con las necesidades humanas en el medio rural, señala la posibilidad de modernizar la tradición, lo que vendría a crear «un estilo propio de arquitectura que recoja de la tradición lo permanente y de los tiempos modernos lo mudable y accesorio ${ }^{58}$. Poco tiempo después analiza esta tipología

\footnotetext{
56 «Viajero ilustre. Arquitectura em Portugal y em Espanha», Op. Cit.

57 «Temas de la tierra. El urbanismo y la aldea» en Faro de Vigo, 30-XII-1925, pág. 1.

${ }^{58}$ CASTILLO LÓPEZ, Á., El patrimonio artístico de Galicia, La Coruña, Tip. El Ideal Gallego, 1926, págs. 33-34.
} 
en el apartado «Torres y pazos», de su colaboración «La Arquitectura de Galicia» en la obra Geografía General del Reino de Galicia. Sánchez Cantón, subdirector del Museo del Prado desde principios de la década de 1920, también se muestra propicio a que la arquitectura gallega tuviera en cuenta la tradición constructiva, los materiales del lugar y el medio geográfico. Este historiador asume la propuesta regionalista que define Eloy Maquieira para su chalé de la carretera de Pontevedra a Marín. El crítico Enrique Estévez Ortega, en su libro Arte Gallego (1930), incluye un capítulo dedicado a Antonio Palacios, a quien reclama un mayor impulso en la concreción de una arquitectura regionalista vinculada a su tierra.

Si bien la insistencia en la mirada a la arquitectura popular fue menor, se localizan iniciativas que no descuidan esa cuestión, como el concurso ${ }^{59}$ de temas de interés para Galicia que convoca en 1921 la revista Mondariz, publicación del afamado balneario del mismo nombre. Bajo el mecenazgo de Enrique Peinador Lines, uno de los pocos industriales que militó en el Partido Galleguista, el balneario contribuyó a la potenciación de la cultura gallega. El concurso se estructuraba en tres secciones, con una dedicada a investigaciones sobre la «antigua casa gallega» en todas sus variantes, desde el pazo hasta las más humildes de labradores o marineros. Uno de los objetivos era realizar «una brillante exposición de obras arquitectónicas característicamente gallegas, la mayor parte ignoradas aún en la misma región y cuyo conocimiento completo, cimentará sólidamente los estudios previos absolutamente indispensables a los arquitectos gallegos del presente, para elevar sobre ellos la creación de la arquitectura regional de un próximo porvenir». Tras el cierre de la muestra el balneario se comprometía a editar un álbum con los estudios más relevantes. El premio de esta sección lo recibió el pintor Carlos Sobrino Buhigas, que ya en la temática de su obra incorporaba imágenes del patrimonio. Circunstancia que enfatizaba la revista organizadora del evento: «Carlos Sobrino ama los porches, los patines, las balconadas de los pazos señoriales, los pasadizos y las arcadas, las casas labriegas y las casas de pescadores, las solanas... cuanto pone sello de arquitectura gallega en aldeas, villas y ciudades»60. En Madrid se había celebrado en 1911 el certamen de la «casa española», dentro de la búsqueda de un estilo nacional del que derivan los regionalismos. En el concurso, organizado por la Sociedad Española de Amigos del Arte, se recomendaba atender al pasado a la hora de definir los proyectos. Dentro de los participantes premiados destaca Leonardo Rucabado con la propuesta «Palacio para un noble en la Montaña».

\footnotetext{
59 «Bases para el primer concurso de la revista Mondariz...» en Mondariz, n 43, 20-VII-1921.

60 «Renacimiento cultural gallego. El concurso de la revista Mondariz», en La Temporada en Mondariz, 28-VIII-1921; Faro de Vigo, 31-VIII-1921, pág. 3.
} 


\section{LA DIVULGACIÓN DE LOS VALORES DEL PATRIMONIO ARQUITECTÓNICO}

En la aceptación social de la tendencia regionalista fue imprescindible la divulgación de los valores del patrimonio, sobre todo de aquellas manifestaciones consideradas de expresión singular en Galicia. Esa divulgación facilitó la compresión por parte del potencial cliente y de la sociedad en general de aquellos elementos que sus arquitectos recogían de la tradición. En relación con el protagonismo que en el ambiente cultural de la época se le condecía a un pasado mitificado y nostálgico, se tendió a resaltar la galleguidad de ciertos monumentos y técnicas constructivas, en especial aquellas relacionadas con el granito. La divulgación contribuyó al fomento del excursionismo, actividad en alza a principios del siglo XX. Diletantes y curiosos comenzaron a visitar los monumentos gallegos y, tras la admiración, apareció la preocupación por su conservación. El propio Antonio Palacios en uno de sus artículos ${ }^{61}$ propone constituir una Sociedad Gallega de Excursiones análoga a las de Madrid. Entre sus fines estaría facilitar el conocimiento de los monumentos mediante recorridos de dos o tres días fijados por una comisión de expertos. La divulgación se reforzó en ocasiones con la opinión de los viajeros extranjeros que se acercaban a Galicia. Un ejemplo significativo son los comentarios que generó la visita en el verano de 1910 de unos veinte periodistas de la British International Association of Journalists de Londres, invitados por la Asociación de Fomento del Turismo de Galicia, creada en Vigo en ese mismo año. Su estancia y los artículos que publicaron a continuación en Inglaterra fueron seguidos con interés. Algunos de ellos, con mención a la riqueza patrimonial de Santiago de Compostela, fueron reproducidos por la prensa gallega ${ }^{62}$. En función de la vocación marítima de la ciudad de Vigo esta asociación estableciera en Londres un comité con una sección de honor y otra ejecutiva, en el que estaban presentes directivos de las agencias de viajes Cook y Lunn y de las compañías navieras Mala Real Inglesa, Booth y Pacífico ${ }^{63}$. En Galicia esta asociación contribuyó a la difusión de la riqueza monumental, mediante el apoyo a la edición de guías y la publicación de algunas propias, como Vigo y sus cercanías.

El fotograbado fue una potente herramienta en la divulgación de los valores del patrimonio y también en la difusión de la arquitectura regionalista. A principios del siglo XX, la mejora de esta técnica permitió la paulatina incorporación de la imagen de los monumentos gallegos a revistas ilustradas y prensa en general. También logró ampliar la producción de álbumes de fotos y de colecciones de postales que se iniciara tímidamente en el siglo anterior. La imagen fotográfica gozó de gran po-

${ }^{61}$ PALACIOS RAMILO, A., «La conservación de nuestro tesoro...» Op. Cit.

${ }^{62}$ El Correo de Galicia (27-X-1910) reproduce un artículo de Arthur H. Moody que alude a la catedral, Pórtico de la Gloria y a la imagen medieval de Santiago. Del mismo autor La Voz de Galicia (3-XI-1910) reproduce otro artículo del periódico The Country Express dedicado a Compostela.

${ }^{63}$ Faro de Vigo, 10-III-1910; El Noticiero, 13 y 14-III-1910. En Santiago también estableció un comité, bajo la presidencia de Salvador Cabeza de León. 
pularidad por su fácil asimilación, mientras los artículos eruditos, e incluso los meramente divulgativos, tuvieron un público muy restringido. La fotografía, además de dar a conocer los grandes monumentos, revalorizó la construcción popular, al difundir tipologías singulares como hórreos, casas con patín, soportales, cruceros, etc. Lo peculiar o «pintoresco» ya había tenido cabida en el grabado de las revistas gráficas del siglo XIX. Vida Gallega fue la primera revista que generalizó la inclusión de fotograbados de elementos del patrimonio, insertados en secciones como «Galicia Arquitectónica y Artística», «Galicia Monumental», «Joyas arquitectónicas», «Galicia Pintoresca», etc. Con grandes tiradas la revista estaba destinada al gran público, mientras otras más eruditas como Nós o la renovadora Alfar solamente llegaban a una elite. En la divulgación fue notable el quehacer de los fotógrafos Luis Casado, Jaime Pacheco, hermanos Sarabia, José Gil, José Manuel Sáenz Mon, etc.

En la prensa se localizan referencias de una nueva apreciación de ciertos elementos del patrimonio, en especial del pazo. Dentro de las primeras series de fotograbados que el periódico Faro de Vigo inserta de forma continuada se encuentra una colección de imágenes de los principales pazos gallegos, recogidas por Javier Ozores Pedrosa. El periódico, que comenzara a incorporar fotograbados de forma intermitente a principios de 1924, inicia la amplia serie «Los Pazos Gallegos» el 29 de enero de 1925 y a lo largo de ese año y parte del siguiente da a conocer un buen número de ejemplos de esta tipología mediante una imagen acompañada de un pequeño comentario. Desde julio de 1925 difunde la estampa de otros monumentos gallegos en la sección «Galicia histórica y arquitectónica». En la misma línea incorpora una serie de dibujos de Carlos Sobrino sobre aspectos paisajísticos y constructivos de la Galicia rural. En el citado periódico también se localizan textos que corroboran la generalización de la demanda de una arquitectura regionalista en medios no ligados al galleguismo. A principios de 1926 en un artículo editorial se aplaude la respuesta de Palacios a esta demanda y se reitera la recomendación de mirada al pazo: «Vigo, en lo moral, tiene ya cierto carácter distintivo. Debiera tenerlo también en lo externo. Nuestra edificación es, en general, suntuosa, pero falta de ese carácter propio. Antonio Palacios proyectó para Porriño, su pueblo natal, un edificio consistorial típicamente gallego. He ahí el ejemplo. El 'pazo' galiciano debiera, a nuestro juicio, ser la causa de la arquitectura local. $\gg 64$.

La difusión de textos divulgativos e imágenes alusivas a la arquitectura histórica está presente en otros periódicos como El Pueblo Gallego, La Voz de Galicia y Galicia (Diaro de Vigo). La divulgación se intensifica en las ediciones especiales de primero del primero de año y del 25 de julio, día de Galicia, en las que se incorpora en ocasiones una tipografía de letra propuesta por Castelao que pretende ser representativa de lo gallego. La búsqueda de una tipografía singular está pre-

64 «El problema de la edificación. Vigo debe tener un carácter propio» en Faro de Vigo, 20-II-1926, pág. 1. 

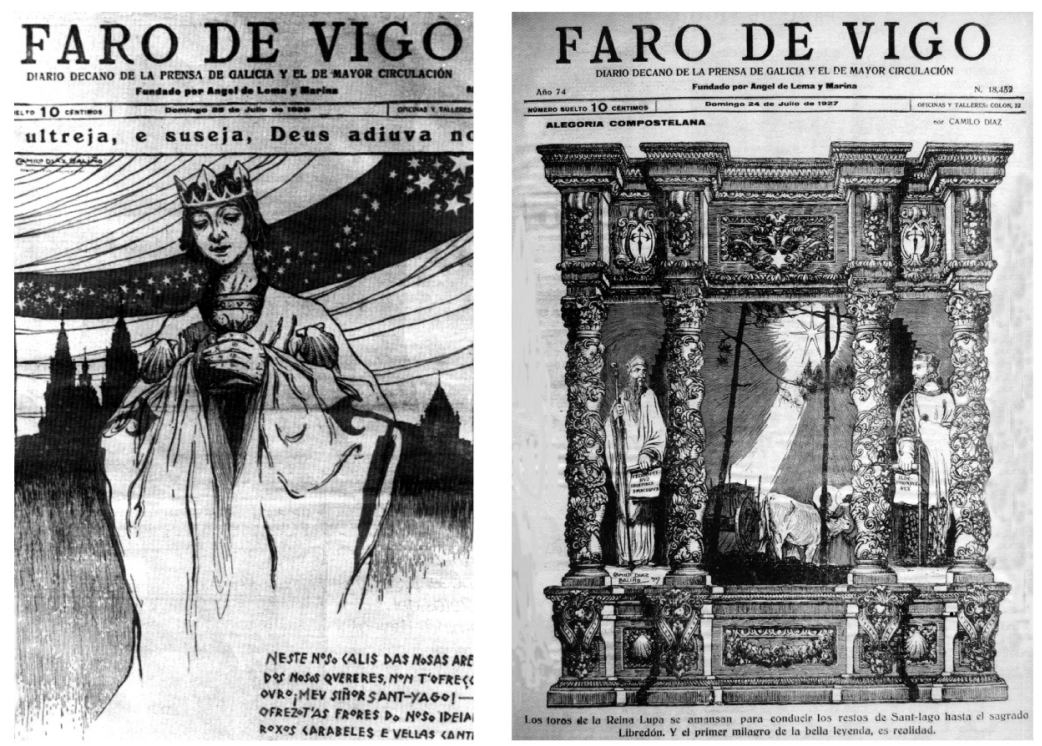

Fig. 6. Primera página del periódico Faro de Vigo del número especial del día de Galicia de los años 1926 y 1927. Diseños de Camilo Díaz Baliño.

sente en otros lugares que desarrollaron también una arquitectura regionalista propia, como es el caso de Euzkadi. Faro de Vigo inició la publicación de estos números especiales en el año 1924. Como en una revista gráfica, toda la primera página se resaltó con diseños de los artistas Camilo Díaz Baliño, Carlos Sobrino, Ignacio Senra, Ramón Peña y Gil Vicario. En ellos aparecía una iconografía repleta de elementos simbólicos de la galleguidad: cruz de Santiago, peregrinos con fondos estrellados, dólmenes, conchas de vieiras, etc. A su lado se incorpora la silueta o la imagen de monumentos, en especial de la catedral de Santiago. Alguna de estas portadas corrobora la recuperación del barroco y la divulgación de sus valores. Díaz Valiño realiza la del 24 de julio de 1927 con un encuadre en forma de retablo barroco que deja ver al fondo una alegoría de la leyenda jacobea de la Reina Lupa (fig. 6 ).

Los arquitectos interesados en el patrimonio, no dejaron de reconocer la importancia de la labor divulgativa. En ese sentido Antonio Palacios destacaba: «Las semillas comienzan a germinar. Las revistas Nós, Céltiga, Vida Gallega, Alfar, los diarios, especialmente los de Vigo y La Coruña, publicando con frecuencia fotografías de nuestra riqueza monumental, los Ateneos, Universidad compostelana, Estudios Gallegos y otros centros y publicaciones son leídos o atendidos con despierta afición por la falange cada vez más numerosa de los entusiastas de nuestro arte regional» ${ }^{65}$. A esa divulgación también contribuyó el editor José Cao

${ }^{65}$ PALACIOS RAMILO, A., «La conservación de nuestro tesoro artístico regional», Op. Cit.. 
Moure (PPKO) que en los «Libros de Oro» de Lugo, A Coruña y Pontevedra o en los "Catálogos» de Vigo y A Coruña, incorporó la estampa de los monumentos gallegos con textos divulgativos de Ángel del Castillo, Sánchez Cantón, Pérez Constanti, Carro García, etc. También contribuyó a la difusión de la tendencia regionalista, con la publicación de proyectos de Manuel Gómez Román, Jenaro de la Fuente Álvarez, Antonio Palacios, etc. En el verano de 1928, en formato de fascículos, Cao Moure inicia la publicación de Los Pazos Gallegos, obra en la que interviene Javier Ozores Pedrosa y el Marqués de Quintanar. En parte, la colección era una ampliación de la citada serie que apareciera en Faro Vigo, con mejora de la calidad gráfica y de la información heráldica e histórica. En un momento de exaltación de lo vernáculo la publicación recibió una favorable acogida: «...el pazo es el símbolo, acaso el más completo, de la cultura de la raza gallega. Ningún otro documento histórico es más vivo, pone con más claridad a los ojos del profano o del investigador la manera de ser de un pueblo"66. Con el mismo formato de cuadernos comienza en 1932 la edición de Relicario Monumental de Galicia, publicación de gran despliegue gráfico que pretendía recoger los elementos más significativos del patrimonio. Cao Moure justificaba la edición por un mayor aprecio de la sociedad de sus monumentos: «El gran interés que despiertan las manifestaciones del arte antiguo, no sólo en las minorías selectas, sino en el gran público (...) hizo cada día más precisa la necesidad de editar el 'Relicario Monumental de Galicia' en cuyas páginas se reproduce con fidelidad las más excelsas obras de arte y las bellezas arquitectónicas que nos legaron nuestros antepasados, contribuyendo con su divulgación a consagrar la personalidad de Galicia en su valoración artística» ${ }^{67}$.

La tarjeta postal fue otro valioso instrumento de divulgación, ya que por su bajo coste alcanzó una gran difusión y llegó a todo tipo de público. La imagen del monumento en la postal tuvo un valor representativo de lo local, al igual que el paisaje, las panorámicas urbanas o las estampas costumbristas. En las postales también tuvo cabida el patrimonio de localidades pequeñas, ya la que enorme popularidad de este medio animó a comerciantes locales a encargar la edición de sus propias colecciones. Además de a los fotógrafos gallegos, la producción de postales interesó a casas editoras foráneas como Hauser y Menet, Luciano Roisin, J. Thomas, etc. Puntualmente la postales incorporaron la imagen de algunas propuestas regionalistas, como es el caso de la casa consistorial de O Porriño. Los fotógrafos también dieron a conocer su trabajo en álbumes, en los que estuvieron presentes imágenes del patrimonio. En 1928 el fotógrafo Luis Casado Fernández (Ksado) publica Estampas Compostelanas, álbum en el que tiene un peso considerable la arquitectura histórica de Santiago. En 1936 edita Estampas de Galicia con un formato singular y popular, ya que las postales eran regaladas por diversos establecimientos comerciales para después ser pegadas en el álbum. La colección se componía de más de cuatrocientas postales, entre las que un importante número recogían aspectos de la riqueza

\footnotetext{
66 «Los pazos gallegos» en El Pueblo Gallego, 12-VIII-1928, pág. 2.

${ }^{67}$ CAO MOURE, J., «Relicario Monumental de Galicia» en Faro de Vigo, 10-I-1932, pág. 12.
} 
monumental gallega. Luis Casado colaboró en el Congreso Nacional de Arquitectura que se celebró en Galicia en el año 1929 con una exposición de fotografías del patrimonio arquitectónico en los salones del Casino de Vigo, ubicados en el teatro García Barbón ${ }^{68}$. El objetivo de la cámara de José Gil se dirigió también a la arquitectura histórica en las películas que rueda entre los años 1910 y 1935, recogiendo los acontecimientos del momento, fiestas, romerías, costumbres, paisajes, etc.

\section{LA ARQUITECTURA COMO VALOR ICONOGRÁFICO DE LO GALLEGO}

En un ambiente de exaltación de lo propio se tendió a resaltar todo aquello que era genuino o enxebre, por lo que ciertos elementos de la arquitectura histórica entraron a formar parte de la iconografía de la galleguidad. En el contexto de la plástica regionalista también la arquitectura formó parte de una temática centrada en lo vernáculo, como se comprueba en la obra de Camilo Díaz Baliño, Manuel Castro Gil, Lino Martínez Villafínez, Julio Prieto Nespereira y Carlos Sobrino. Este último destacó entre todos por incorporar elementos del patrimonio a gran parte de su obra, tanto en la pintura como en la ilustración. En 1926 Vilar Ponte ${ }^{69}$ lo calificaba como el «pintor de los rincones históricos y tradicionales; el artista divulgador de nuestras cosas etnográficas; el acuarelista y dibujante de la arquitectura gallega». En la misma línea Villafínez acoge en sus cuadros a la Compostela monumental, con predilección por la catedral y Pórtico de la Gloria. Los grandes monumentos y la arquitectura popular están presentes en los grabados de Castro Gil y Julio Prieto Nespereira. La obra gráfica de Castelao revela aprecio al medievo en el diseño de letras, colofones, ilustraciones, viñetas, etc. Por su parte, los arquitectos se integraron en el ambiente artístico de la época. González Villar y Palacios participaron en la organización de algunas exposiciones de «Arte Gallego» celebradas en las principales ciudades gallegas, Madrid, Buenos Aires y Montevideo entre 1912 y 1928. Su colaboración se amplió a la exhibición de proyectos de corte regionalista en alguno de estos certámenes.

El cartel publicitario refleja con precisión la progresiva identificación de la sociedad con sus monumentos, ya que en sus dos niveles de lectura, icónico y literario, debía ser fácilmente comprendido por público. La presencia de elementos del patrimonio en carteles significaba su aceptación como valor iconográfico de lo propio $^{70}$. En una ocasión tan representativa de lo gallego como la celebración de la Exposición Regional de Santiago de 1909 el pintor Francisco Llorens emplea

68 «El casino de Vigo», en Faro de Vigo, 19-I-1929.

${ }^{69}$ VILLAR PONTE, A., "Ante la exposición de Carlos Sobrino» en El Pueblo Gallego, 30-V-1926, págs. 1-2.

${ }^{70}$ Vid. SOBRINO MANZANARES, Mํㅡㄴ L. O cartelismo en Galicia. Desde as súas orixes ata 1936, Sada (A Coruña), Edicións do Castro, 1993. En muchos carteles gallegos de principios del siglo XX fueron frecuentes las alusiones a la arquitectura gallega románica y barroca. 


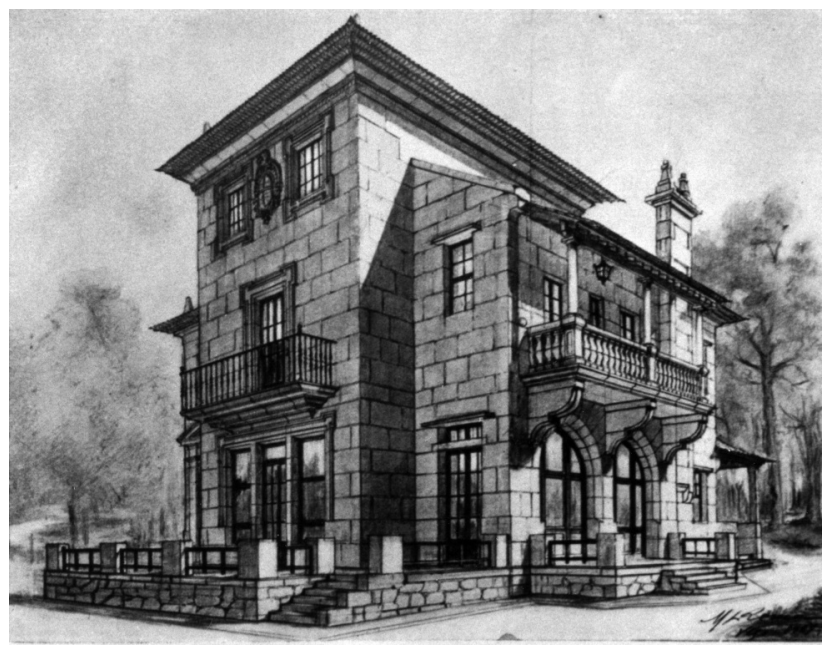

Fig. 7. Perspectiva del chalet del industrial conservero Rodrigo Alonso Jiménez Cuenca. C. 1926 (Vigo en 1927. PPKO).

como fondo del cartel la imagen de la fachada de Platerías de la catedral compostelana. La silueta de este monumento también la introduce Camilo Díaz Baliño en los carteles que diseña con motivo de las fiestas de Santiago. Carlos Sobrino vuelve a mostrar la portada románica de Platerías en el que confecciona en 1926 para el Patronato Nacional de Turismo. Una mayor variedad de elementos del patrimonio se dan cita en los realizados para la Exposición Iberoamericana de Sevilla de 1929, como se comprueba en los que promocionan Pontevedra, Combarro, Santiago de Compostela, Viveiro y la aldea del Cebreiro. En el cartel de Vigo el pintor Maside incorpora, con un tratamiento más moderno, una evocación del barrio de pescadores del Berbés. El empleo de ciertos monumentos o de alguna de sus partes como icono de lo gallego afectó, aunque en menor mediada, a la publicidad comercial. En el mundo editorial, Mercedes Bangueses ${ }^{71}$ ha puesto de relieve en su estudio sobre la ilustración, como elementos de la arquitectura histórica se incorporan al diseño de capas al lado de otros iconos que proclaman el carácter gallego del libro. Esas alusiones van desde la primera arquitectura gallega representada por el dolmen a manifestaciones del románico o del barroco.

En la concreción de una arquitectura regionalista se comprueba, mejor que cualquier otro campo, la nueva valoración que alcanza el barroco. Como representativo de lo gallego el arquitecto Miguel Durán-Loriga Salgado elige el refe-

${ }^{71}$ BANGUESES VÁZQUEZ, M., A ilustración del libro en Galicia. Céltiga, Lar, Nós, editoriais con inquietude artística. Santiago, Xunta de Galicia, CGAC, 2008. 
rente del pazo y del barroco de placas compostelano para el pabellón de Galicia en la Exposición Iberoamericana de Sevilla de 1929. Durán no hacía más que seguir la propuesta neobarroca que Manuel Gómez Román y otros arquitectos habían definido y probado con éxito en los años anteriores (fig. 7). Como en otras ocasiones el aplauso al leguaje del pabellón fue general y la prensa resaltó complacida las notas recogidas de las casas compostelanas del Cabildo y del Deán. La atención prestada al pazo se constata en el propio catálogo oficial de la exposición, que incluye un estudio de Javier Ozores y del conde de Santibáñez del Río sobre esta tipología del campo gallego ${ }^{72}$.

A la vía neobarroca se adhirieron, con mayor o menor grado de fortuna, los arquitectos Gómez Román, Cominges, Rodríguez Losada, Jenaro de la Fuente Álvarez, Banet, Salgado Urtiaga, Argenti Navajas, etc. Uno de los contenidos que adoptaron la mayoría de estos profesionales fue el empleo de granito y de sus técnicas de uso avaladas por una tradición milenaria. También en la personal versión regionalista de Antonio Palacios la presentación ruda y brutal de este material se convirtió en ingrediente básico. La propia investigación resaltaba como el granito, manejado por expertos maestros canteros, había conferido a la arquitectura popular y a los estilos históricos una expresión particular. Este noble material, además de ser abundante en gran parte de la geografía gallega y concordante con el paisaje, era reconocido como propio por la sociedad. Su utilización se asumió como un componente diferenciador de un regionalismo de contenidos galaicos. Ese carácter lo apreciaron profesionales no gallegos, como Pedro Muguruza, que al comentar ${ }^{73}$ sobre la cita regionalista de la Exposición de Sevilla, indicaba: «En esa sucesión paralela de tipos, bien análogos, es ya fórmula admitida una calificación rotunda de "estilo vasco»; «estilo montañés», etc., siendo a mi juicio, punto menos que imposible limitar unos de otros, allí donde las costumbres han sido casi idénticas, donde los materiales apenas se diferencian en su clase; marcando, por tanto variantes imperceptibles en su uso. Más fácil de definir y limitar, en cambio, la arquitectura gallega, donde existe un material, la piedra granítica, en cuyo peculiar empleo se producen formas típicas y elementos característicos». El granito fue manejado en una amplia gama de presentaciones, que van desde el primitivismo de las piezas sin labra en la creación de Palacios a la delicada sillería y cuidada ornamentación de la mayoría de las obras, incluidas las propias de la arquitectura doméstica. También se emplearon soluciones intermedias que no dejan de mirar al barroco, como el reservar la fina cantería para elementos singulares como recercado de vanos, ornamentación, cornisas, zócalos, balaustradas, etc., mientras los entrepaños se ejecutaban de "cachotería» revestida de mortero de cal. Con estos entrepaños blancos se aligeraba la pesadez de las grandes fábricas de granito (fig. 8 ).

72 OZORES PEDROSA, X., y CONDE DE SANTIBÁÑEZ DEL RíO, «Los pazos gallegos» en Libro de Oro Ibero-Americano., Unión Ibero-Americana (Aldus, artes gráficas), 1928-1929, págs. 643-645. 


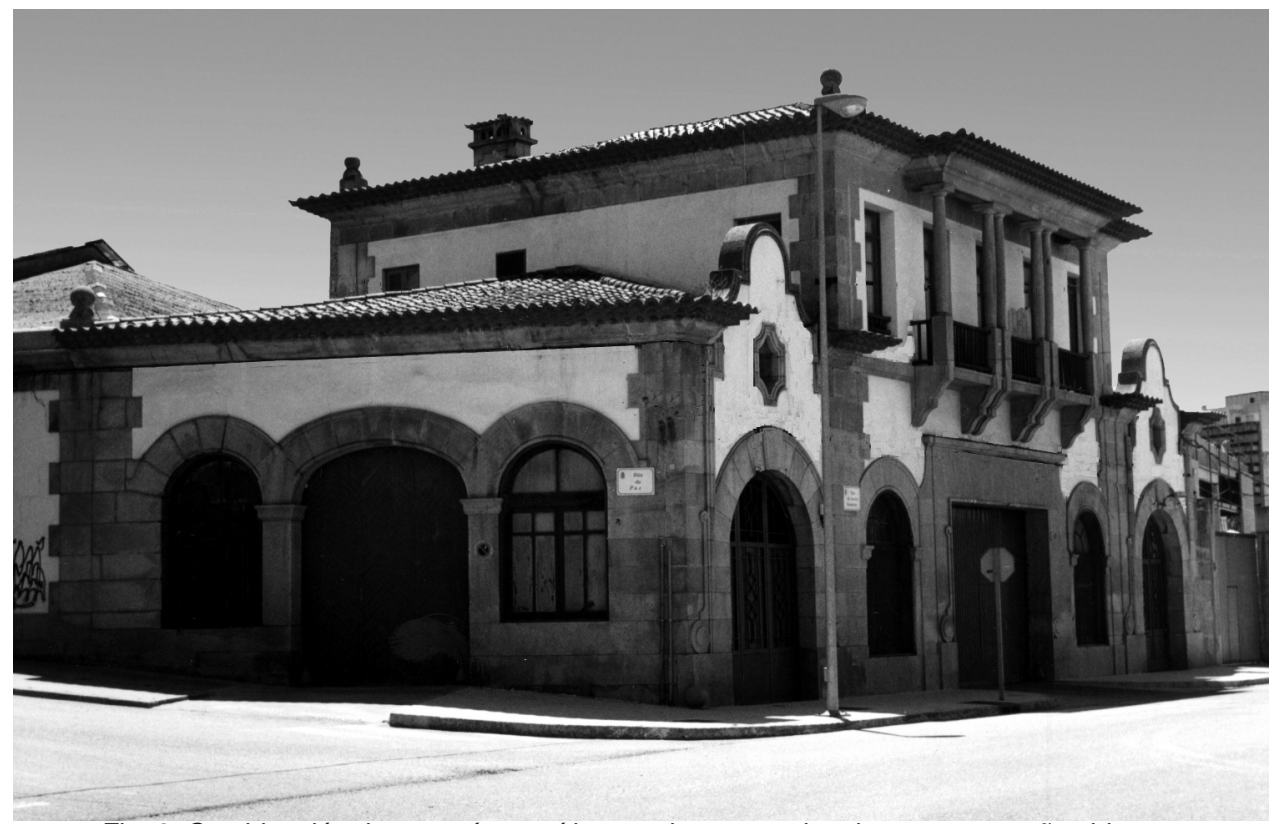

Fig. 8. Combinación de cantería granítica en elementos singulares y entrepaños blancos. Fábrica de conservas Albo de la calle Paz, esquina a Jacinto Benavente. Vigo. C. 1929. Jenaro de la Fuente Álvarez.

A excepción de Palacios y González Villar, la obra del resto de arquitectos gallegos refleja la nueva valoración del barroco, en especial la ligada a la obra Simón Rodríguez y Clemente Fernández Sarela. Esta variante de placas, caracterizada por el predominio de formas geométricas con superficies planas y recortadas que en parte impone el uso del duro granito, había sido difundida por los maestros canteros por toda la geografía gallega e incorporado en el medio rural a un gran número de pazos e iglesias que ser remozan o amplían en el siglo XVIII. La vía neobarroca de regionalismo gallego afectó a todas las tipologías, pero su principal éxito lo obtuvo en la vivienda unifamiliar burguesa. Entre los contenidos formales que adopta se encuentran solanas, soportales, balaustradas pétreas, pináculos de bola, placas de formas mixtilíneas, prominentes chimeneas, pilastras cajeadas, recercados de vanos con molduras y orejeras, peinetas, frontones partidos, volutas, etc. La vía neobarroca se adaptó también a la vivienda media y humilde mediante una depuración de su carga decorativa, pero conservando algunos de sus rasgos característicos y sobre todo los magníficos tratamientos graníticos. En general la atención al pazo no tuvo un carácter mimético, sino que la referencia al modelo histórico quedó condicionada por influencia de la arquitectura pintoresca del cottage inglés y de sus variantes naci-

${ }^{73}$ MUGURUZA, P., «La arquitectura regional española» en Libro de Oro Ibero-Americano, Op. Cit., pág. 375 


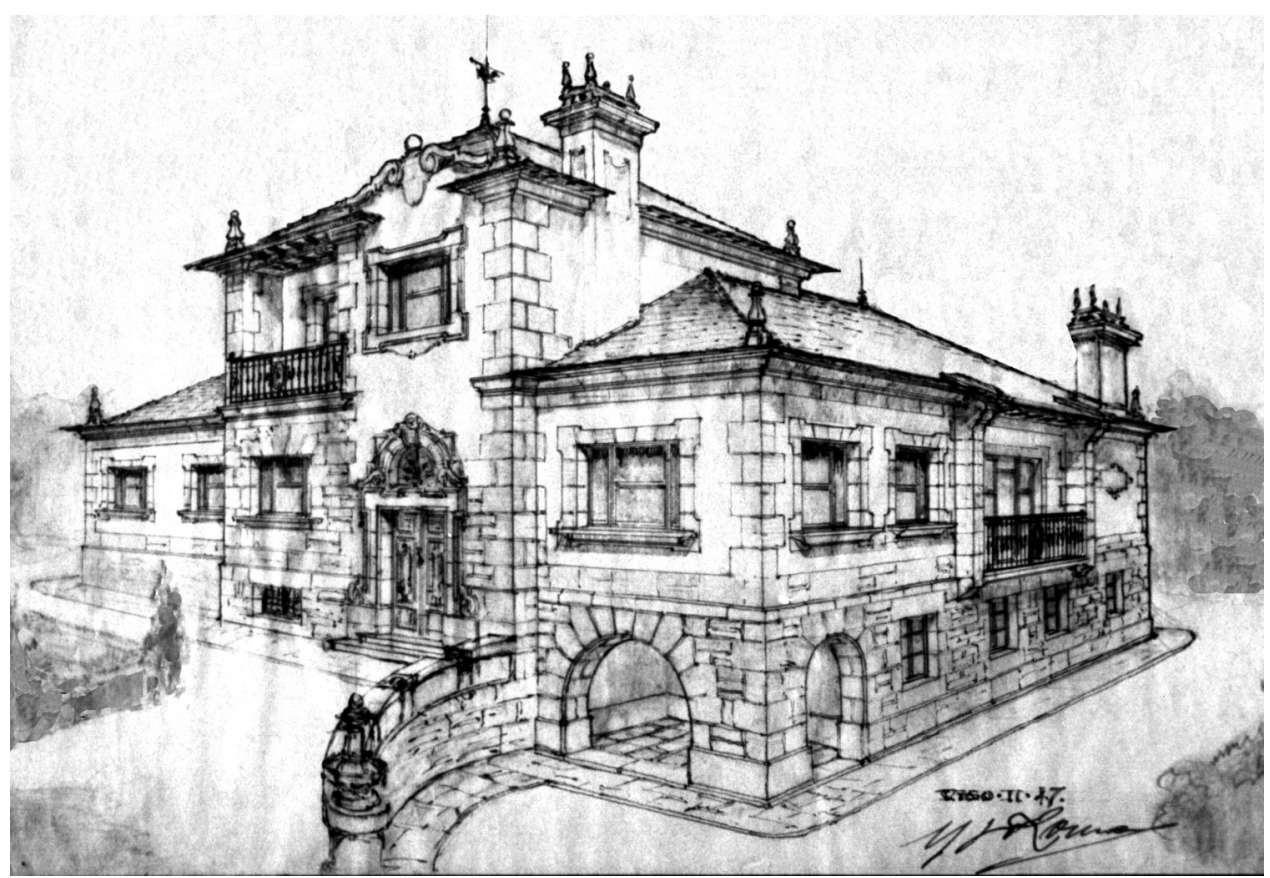

Fig. 9. Propuesta de chalet regionalista. Manuel Gómez Román. (Fundación Penzol. Vigo).

das por todo el continente europeo. Lo pintoresco había alterado los principios clásicos de orden y simetría, con lo que en la vivienda burguesa apareció el gusto por la asimetría, por lo irregular, por los volúmenes quebrados, por lo insólito y dispar. Esa influencia provocó una transgresión en la recreación del modelo histórico de pazo que rompió su estática configuración con la presencia de ciertas asimetrías, yuxtaposición de volúmenes, animación de las cubiertas con un mayor número de aguas del tejado, incorporación de buhardillas, adopción de miradores tipo bay, bow y oriel window y ornamentación de la cubierta con pináculos y potentes chimeneas (fig. 9). También se perfilaron soluciones nuevas y ajenas a la tradición constructiva local, como el uso masivo del alero volado de «broca», formado por una triple fila de teja curva (fig. 10). Con todo, la incorporación de novedades, no restó la monumentalidad y severidad que, al igual que en los pazos, confería la presencia del granito. La importancia concedida a la cantería granítica como valor de lo propio impuso sus condiciones y le otorgó a gran parte de la producción regionalista gallega un carácter sobrio y un porte monumental. 


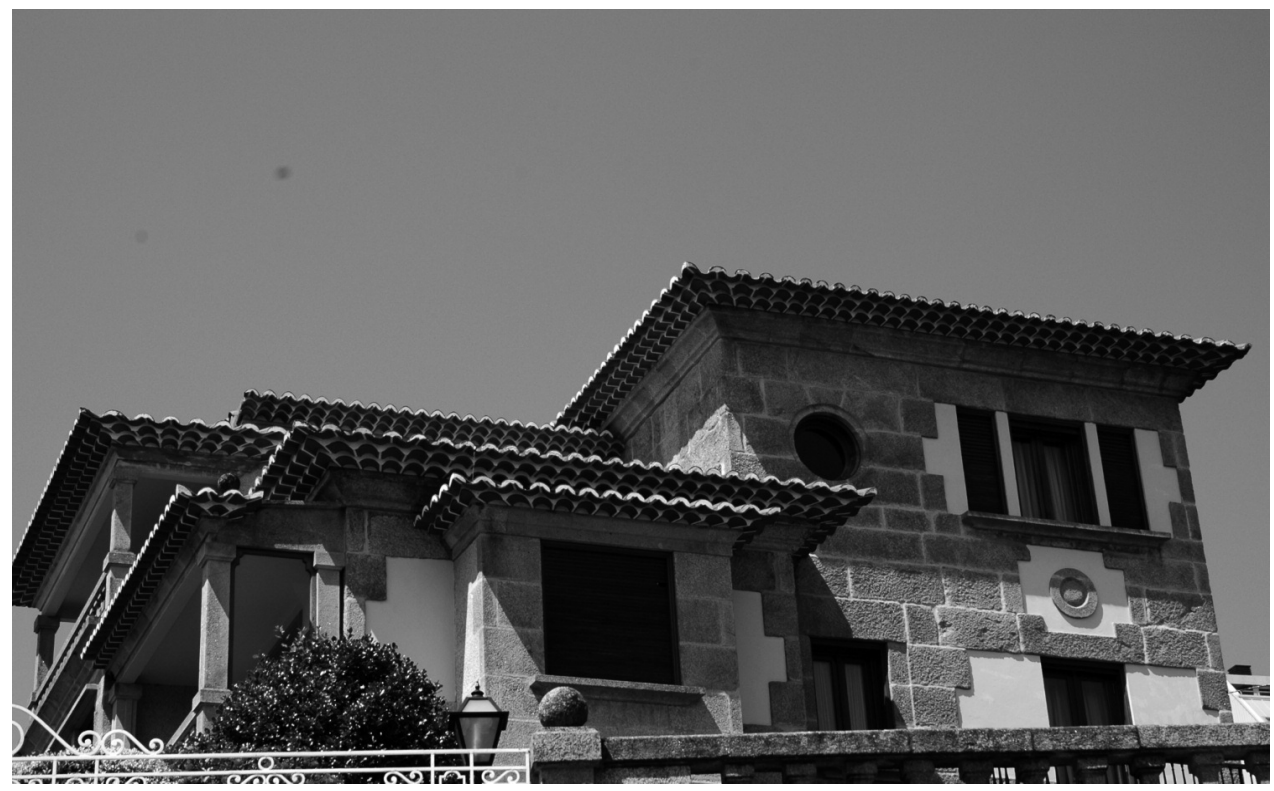

Fig. 10. Aleros de "broca" del chalet de Eduardo González de las calles Gondomar y Couto de la zona residencial del Castro en Vigo. 1945. Antonio Cominges Tapias. 